\title{
Human Health Risk Assessment and Potentially Harmful Element Contents in the Cereals Cultivated on Agricultural Soils
}

\author{
Agnieszka Gruszecka-Kosowska \\ Department of Environmental Protection, Faculty of Geology, Geophysics, and Environmental Protection, \\ AGH University of Science and Technology, Al. Mickiewicza 30, 30-059 Kraków, Poland; \\ agnieszka.gruszecka@agh.edu.pl
}

Received: 30 January 2020; Accepted: 2 March 2020; Published: 4 March 2020

\begin{abstract}
Potentially harmful element (PHE) contents were investigated in six species of cereals in southern Poland, with human health risk implications assessed afterwards. The PHE contents belonged to the following ranges ( $\mathrm{mg} / \mathrm{kg}$ wet weight): As below the limit of detection $(<\mathrm{LOD})-0.013$, Cd <LOD-0.291, Co <LOD-0.012, Cu 0.002-11.0, Hg <LOD-0.080, Ni <LOD-8.40, Pb <LOD-12.0, Sb $<$ LOD-0.430, Tl <LOD-0.160, and $\mathrm{Zn} \mathrm{5.47-67.7.} \mathrm{The} \mathrm{Pb} \mathrm{and} \mathrm{Cd} \mathrm{contents} \mathrm{exceeded} \mathrm{the} \mathrm{maximum}$ allowable concentration (MAC) values for wheat, oat, rye, and barley in the Slaskie region. The bioaccumulation coefficient (BA) for the total PHE content in the soil indicated that cereals had no potential of PHE accumulation. Regarding the statistical daily consumption of cereals, the PHE intake rates, expressed as a percentage of permissible maximum total daily intake (\% PMTDI), were the following: As 0.0003, Cd 0.193, Co 0.0003, Cu 0.075, $\mathrm{Hg}$ 0.424, Ni 3.94, Pb 3.16, Sb 0.23, Tl 0.27, and $\mathrm{Zn} 0.44$. The total non-carcinogenic risk values (HQ) exceeded the target risk value of 1 for wheat $(\mathrm{HQ}=13.3)$ and rye $(\mathrm{HQ}=3.44)$. For other cereals, the total non-carcinogenic risk values decreased in the following order: barley $(\mathrm{HQ}=0.47)>$ oat $(\mathrm{HQ}=0.38)>$ maize $(\mathrm{HQ}=0.02)$. The total non-carcinogenic risk value of the statistical daily consumption of cereals was acceptable low (HQ = 0.58). The acceptable cancer risk (CR) level of $1.0 \times 10^{-5}$ investigated only for As was not exceeded under any of the intake scenarios. Concerning the mean As content in cereals consumed daily in statistical amounts the $\mathrm{CR}$ value was equal to $5.1 \times 10^{-8}$. The health risk value according to the $\mathrm{Pb}$ content in cereals using the margin of exposure (MOE) approach was equal to 1.27, indicating an acceptable low risk.
\end{abstract}

Keywords: potentially harmful elements; cereals; agricultural soil; human health risk assessment; bioconcentration factor; dietary intake

\section{Introduction}

Cereals are the staple food in the human diet of the population worldwide. Globally, the daily consumption of cereals (403 g/person per day) is higher than that of vegetables ( $385 \mathrm{~g} /$ person per day) and fruits (213 g/person per day) [1]. Cereals and breads are the main source of energy in all age groups, and they contribute $31 \%$ of digestible energy to adults [2]. Each cereal plays an important role in various food industry areas: barley is used in beer production, wheat and rye are used in bakery products, oats are used in oatmeal and muesli, and triticale, besides being the main ingredient of animal feed, is also used on a smaller scale in bread, cookies, or cakes [3]. In the nutritional pyramid, the healthy diet comprises from four to six servings of grains daily [4]. Cereals are substantial sources of carbohydrates, dietary fiber, water-soluble vitamins, minerals, proteins, amino acids, phytochemicals (phenolics and terpenoids), and methyl donors (betaine, choline) [1,2]. 
For many years, so-called heavy metals have been contaminants of special concern due to their persistence in the environment and their ability to accumulate in ground or soil. Due to the fact that metalloids are included among them, the term "trace elements" is also used [5]. However, some trace elements are also essential for living cells, i.e., micronutrients such as $\mathrm{Zn}, \mathrm{Cu}, \mathrm{Co}, \mathrm{Cr}$ (III), and $\mathrm{Ni}$, depending on the organism [6]. Nevertheless, as the dose makes the poison, quoting Paracelsus, intake of higher amounts of essential elements than needed can cause the occurrence of negative health effects $[7,8]$. On the other hand, some trace elements are redundant for living organisms; thus, any dose may cause toxic effects. Hence, the term potentially harmful elements (PHEs) takes into account all of the above [9]. Exposure to PHEs and their accumulation in humans may cause many toxic health effects, including reproductive toxicity, neurotoxicity, immune suppression, birth defects, and behavioral or developmental changes $[10,11]$. PHEs are also involved in the emergence of such diseases as Alzheimer's disease, Parkinson's disease, osteoporosis, or multiple sclerosis [12]. Moreover, some of them are considered to be carcinogenic to humans, i.e., $\mathrm{As}, \mathrm{Cd}, \mathrm{Cr}, \mathrm{Co}, \mathrm{Ni}$, and $\mathrm{Pb}$ [13].

As the environment becomes more and more polluted with PHEs in agriculture, especially with fertilizers, fungicides, and agrochemicals used for crop protection purposes, as well as rapidly expanding urban and industrial areas and related atmospheric contaminant depositions [14-17], soil and food crop quality has become a serious health issue worldwide [12,18-27]. Moreover, special concern has started to be paid to baby foods, as recent research of Houlihan and Brody [28] revealed that $95 \%$ of baby foods were contaminated by at least one of the heavy metals, and the most common heavy metals in baby foods were $\mathrm{As}, \mathrm{Cd}, \mathrm{Hg}$, and $\mathrm{Pb}$.

Cereals are the main components of the daily diet. Thus, it is justified to hypothesize that the intake of seeds containing even low concentrations of PHEs may cause health risks owing to long-term consumption of cereals. Research of arable soils in southern Poland, where investigated cereals were cultivated, revealed that total permissible PHE contents were not exceeded in these soils [29]. However, bioavailable PHE contents were found in investigated soils [30]. The precise use of fertilizers, particularly in the analyzed soils, was not known, however due to rather weak soil production properties in Poland [31], mineral and organic fertilizers, and the food protection products are commonly used in Polish agriculture [32]. Moreover, vegetables, investigated precisely on these analyzed soils, were enriched in PHEs, and non-carcinogenic health risks related to their consumption exceeded the target risk value of 1 [33]. In the case of cultivated fruits on investigated soils, it was revealed that berry, stone, and pome fruits had the potential to accumulate PHEs [34]. Thus, in the case of cereals, which are the major source of daily diet composition, the current research seemed to be important and justified.

The goal of the present study was to determine selected PHE concentrations in commonly cultivated cereals on arable soils in southern Poland and to conduct a health risk implication assessment. The detailed objectives of the study included the following: (1) the determination of $\mathrm{As}, \mathrm{Cd}, \mathrm{Co}, \mathrm{Cr}, \mathrm{Cu}$, $\mathrm{Hg}, \mathrm{Ni}, \mathrm{Pb}, \mathrm{Sb}, \mathrm{Se}, \mathrm{Tl}$, and $\mathrm{Zn}$ contents in six species of cereals (barley, maize, oat, rye, triticale, and wheat), (2) the calculation of soil-to-plant transfer indices, (3) the determination of PHE contributions to the daily intake rates via cereal consumption, and (4) a human health risk assessment of the PHE contents in consumed cereals.

\section{Materials and Methods}

\subsection{Cereal Sampling and Preparation}

Previously, total [29] and bioavailable [30] contents of potentially harmful elements were investigated in arable soils of southern Poland. Subsequently, edible plants commonly cultivated in Poland on the above-described soils were further analyzed and described with respect to vegetables [33] and fruits [34]. The results presented in this paper focus on cereal investigations. In the four regions of southern Poland, namely Opolskie, Ślaskie, Małopolskie, and Świętokrzyskie (Figure 1), during the growing seasons of 2015 and 2016, six species of cereals commonly cultivated in Poland were 
investigated (Table 1). Cereal samples were obtained directly from farmers. Not all the cereal species were collected in all investigated regions due to the research assumption that cereals had to be cultivated directly on arable soils previously investigated [29,30]. Thus, altogether 18 cereal samples were analyzed. After transportation to the laboratory, cereals were washed, and seeds were placed on open porcelain dishes and dried under radiant lamps at $70^{\circ} \mathrm{C}$. Dried cereal samples were then ground into coarse powder using a ceramic coffee grinder and stored in sealed bags for further analysis. The grinder was cleaned after each cereal sample processing to prevent cross-contamination.

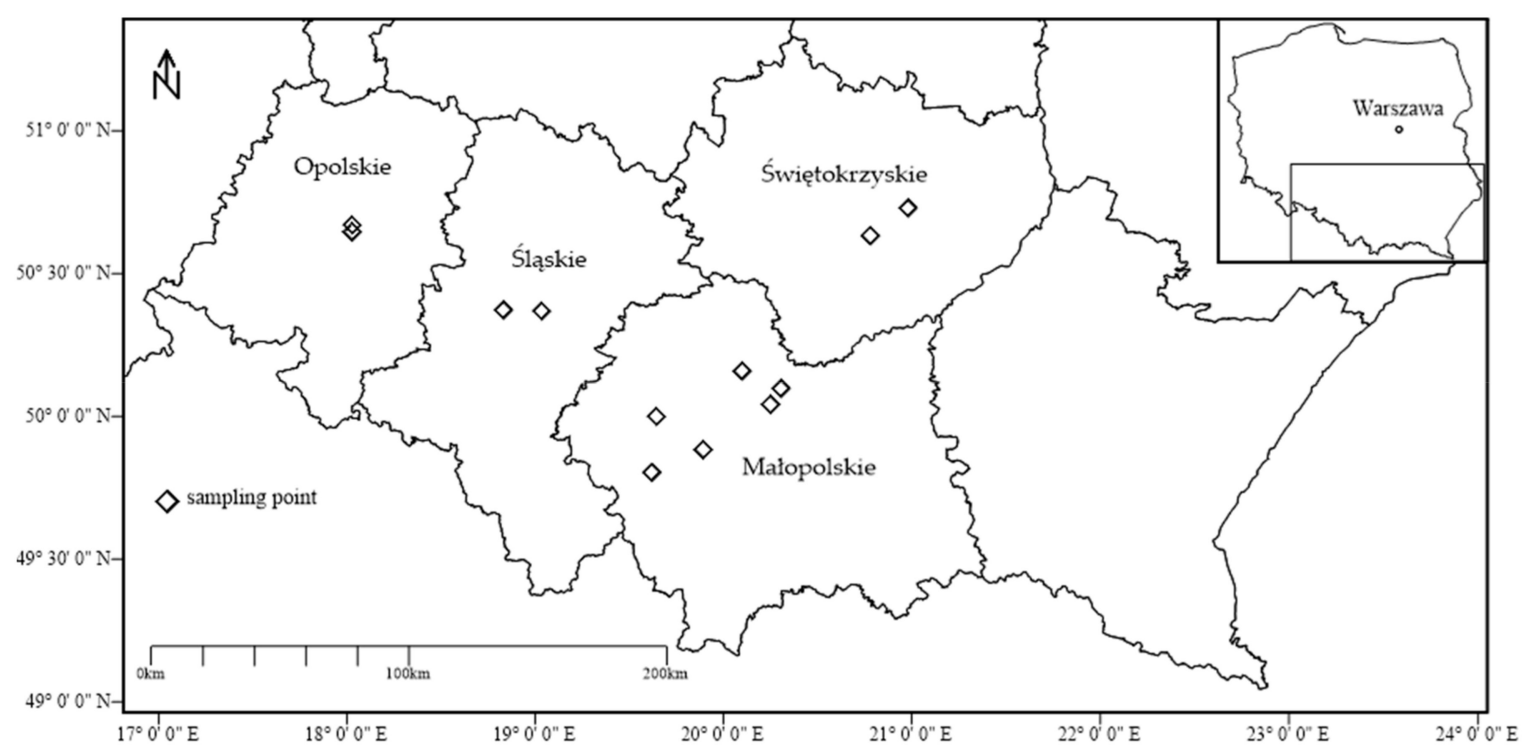

Figure 1. Cereal sampling site locations in the four regions of southern Poland (modified from [34]).

Table 1. Description of the cereals investigated in this study.

\begin{tabular}{ccccc}
\hline No. & Common Name & Scientific Name & Number of Samples & Edible Part \\
\hline 1 & Barley & Hordeum vulgare & 3 & seed \\
2 & Maize & Zea mays & 3 & seed \\
3 & Oat & Avena sativa & 2 & seed \\
4 & Rye & Secale cereale & 2 & seed \\
5 & Triticale & ×Triticosecale & 2 & seed \\
6 & Wheat & Triticum aestivum & 6 & seed \\
\hline
\end{tabular}

\subsection{Sample Analyses}

Cereal samples $(0.5 \mathrm{~g}$, accurate to $0.001 \mathrm{~g})$ were weighed and placed in mineralization flasks, with $15 \mathrm{~mL}$ of $\mathrm{HNO}_{3}$ and $5 \mathrm{~mL}$ of $\mathrm{H}_{2} \mathrm{O}_{2}$ added. Samples were left for decomposition of organic matter overnight. The next step involved digestion in the SCP Science DigiPREP HT High Temperature Digestion System (SCP Science, Quebec, Canada) for $2 \mathrm{~h}$ at $130{ }^{\circ} \mathrm{C}$. After cooling down the extract solutions, their volume was expanded to $50 \mathrm{~mL}$ using ultrapure water. At the same time, blank and reference samples (white cabbage, Certified Reference Material BCR ${ }^{\circledR}-679$, European Commission, Joint Research Centre, Institute for Reference Materials and Measurements) were prepared. The total concentrations of the investigated PHEs ( $\mathrm{As}, \mathrm{Cd}, \mathrm{Co}, \mathrm{Cr}, \mathrm{Cu}, \mathrm{Hg}, \mathrm{Ni}, \mathrm{Pb}, \mathrm{Sb}, \mathrm{Se}, \mathrm{Tl}$, and $\mathrm{Zn}$ ) were determined by inductively coupled plasma-mass spectrometry ICP-MS (ELAN 6100; Perkin Elmer, Waltham, MA, USA), according to United States Environmental Protection Agency (USEPA) 6020B [35] and ISO 17294-2:2003 [36] protocols. 
All the results of the PHE concentrations in the cereals were referred to by wet weight (ww), in accordance with Equation (1) [37]. Water content in particular plant samples was taken from the USEPA exposure factors book [37]:

$$
c_{w w}=c_{d w} \times(100-w) / 100
$$

where $\mathrm{c}_{\mathrm{ww}}$-concentration of PHE in plant sample wet weight, $\mathrm{c}_{\mathrm{dw}}$-concentration of PHE in plant sample dry weight, and $\mathrm{w}$-percentage water content.

\subsection{Quality Control}

Cereal sample analyses were performed, observing standard certified analytical quality control procedure ISO 17294-1:2007 [38]. To achieve impartial and unequivocal ICP-MS results, all investigated PHEs were also measured using inductively coupled plasma-optical emission spectroscopy ICP-OES (OPTIMA 7300DV; Perkin Elmer, Waltham, MA, USA) according to USEPA 6020B [35] and ISO 11885:2009 [39] protocols. The certified reference material (white cabbage, Certified Reference Material $\mathrm{BCR}^{\circledR}-679$ ) was analyzed at the same time. Recovery from the Certified Reference Material $B C \mathrm{R}^{\circledR}-679$ was between $83 \%$ and $124 \%$ for the majority of the analyzed PHEs. Method reagent blanks and duplicates were used to provide quality assurance and quality control. All the reagents used in the laboratory analysis were analytically pure. The results of the samples were contained within the allowable error change values. Analytical bias was statistically insignificant $(p=0.05)$. Precision measurements of the ICP-MS and ICP-OES systems were satisfactory, verified by six different solution injections. Rh was used as an internal standard. Element correction equations were used for each element so that the ICP-MS analysis minimized the impact of interferences. The limit of detection of the instrument (LOD) values of the investigated PHEs were as follows $\left(\mu \mathrm{g} / \mathrm{dm}^{3}\right)$ : As $<0.001, \mathrm{Cd}<$ 0.0005, $\mathrm{Co}<0.0005, \mathrm{Cr}<0.0005, \mathrm{Cu}<0.0005, \mathrm{Hg}<0.001, \mathrm{Ni}<0.002, \mathrm{~Pb}<0.0005, \mathrm{Sb}<0.0005, \mathrm{Se}<$ $0.002, \mathrm{Tl}<0.001$, and $\mathrm{Zn}<0.001$.

\subsection{Statistical Analysis}

Statistical analysis involved the determination of mean, standard deviation, and minimum and maximum values using a Microsoft Excel 2007 spreadsheet. The software package STATISTICA 13 (TIBCO Software Inc., Palo Alto, CA, USA) was used to check data distribution using the Shapiro-Wilk's test $(p=0.05)$, while hierarchical cluster analysis (HCA) and principal component analysis (PCA) were performed for the multivariate statistical modeling of the input data. Halves of the limit of detection values were assigned to undetected results in all performed statistical analyses, as recommended by the World Health Organization (WHO) [40].

\subsection{Soil-To-Plant Transfer Indices}

Two soil-to-plant transfer factors were used in the current research for investigating if determined total and bioavailable PHE contents in analyzed soils significantly affected their concentrations in consumed cereal seeds. The bioaccumulation coefficient (BA) described the transference of PHE from soil to plant, while the bioconcentration coefficient (BC) described plant capacity to adsorb PHE from soil when PHE occurred in an available form [41]. The BA and BC values were calculated for the investigated groups of cereals, respectively, from Equations (2) and (3) according to [42]:

$$
\begin{aligned}
& \mathrm{BA}=\mathrm{C}_{\text {cereals }} / \mathrm{C}_{\mathrm{st}} \\
& \mathrm{BC}=\mathrm{C}_{\text {cereals }} / \mathrm{C}_{\mathrm{sa}}
\end{aligned}
$$

where $\mathrm{C}_{\text {cereals }}$ is the mean concentration of a particular PHE $(\mathrm{mg} / \mathrm{kg} \mathrm{ww})$ in the investigated cereal seeds; $C_{\text {st }}$ is the mean total concentration of a particular PHE, determined in the soil samples $(\mathrm{mg} / \mathrm{kg}$ $\mathrm{dw}$ ) from southern Poland, using aqua regia digestion [29]; and $\mathrm{C}_{\mathrm{sa}}$ is the mean available concentration 
of a particular PHE, determined in the soil samples $(\mathrm{mg} / \mathrm{kg} \mathrm{dw})$ from southern Poland after extraction with the following: (i) $0.11 \mathrm{M} \mathrm{CH}_{3} \mathrm{COOH}$ (the first fraction of the Community Bureau of Reference BCR sequential extraction procedure F1) and (ii) $0.05 \mathrm{~mol} / \mathrm{dm}^{3} \mathrm{Na}_{2}$ EDTA [30]. The contents of PHEs used for calculations of soil-to-plant transfer indices are given combined in Table S1 based on previous soil investigations $[29,30]$.

\subsection{Human Health Risk Assessment}

The point estimate method developed by the USEPA [43] was applied to assess the human health risk analysis (HHRA) arising from the consumption of PHEs in the cereals cultivated in southern Poland. Using the mean and the 95th percentile (P95) of the PHE concentrations in the cereals, the following parameters were calculated for both adults and children: the daily intake rate (DIR) values for particular PHEs were calculated as the sum of consumed cereals according to Equation (4) [44]:

$$
\mathrm{DIR}=\Sigma\left(\mathrm{C}_{\text {cereals }} \times \mathrm{IR}_{\text {cereals }} / \mathrm{BW}\right)
$$

where $\mathrm{C}_{\text {cereals }}$ is the concentration of a particular PHE in the group of cereals $(\mathrm{mg} / \mathrm{kg} \mathrm{ww})$; IR is the cereals ingestion rate (g/person per day) in the group of cereals; and BW is body weight: $70 \mathrm{~kg}$ for adults and $15 \mathrm{~kg}$ for children [37].

The intake rates of cereals assumed in this study are presented in Table 2. Three exposure scenarios of cereal consumption were analyzed. The first scenario was based on the available Polish data concerning statistical cereal consumption by adults [45]. The second and third ones were based on the recommended number of servings of cereals per day for adults and children, respectively [4]. The recommended values [4] describe the amounts of cereals that should be consumed daily when one follows healthy diet suggestions. As, in fact, these amounts of cereals are still rarely consumed, they were also chosen to represent the highest amount of cereals consumed in the calculated HHRA analysis performed.

Table 2. Intake rates (IR), in g of wet weight (ww)/person per day, of the consumed species of cereals.

\begin{tabular}{cccc}
\hline \multicolumn{4}{c}{ IR (g ww/Person Per Day) } \\
\hline Type of Cereals & Adult PL & Adult RDI & Child RDI \\
\hline Barley & 0.78 & 13.3 & 8.85 \\
Maize & 0.16 & 2.69 & 1.79 \\
Oat & 0.09 & 1.58 & 1.05 \\
Rye & 5.68 & 96.4 & 64.4 \\
Triticale & $-*$ & $-{ }^{*}$ & - \\
Wheat & 27.8 & 471 & 314 \\
Sum & 34.5 & 585 & 390 \\
\hline
\end{tabular}

adult PL—intake rate for adults, statistical data for Poland [45]; adult RDI—recommended daily intake rate for adults [4]; child RDI—recommended daily intake rate for children [4]; *-no intake rate reported [45].

The average daily doses (ADD) for PHE ingestion via consumed cereals ( $\mathrm{mg} / \mathrm{kg}$ bw per day) were calculated as the sum of the consumed cereals using Equation (5) according to [43]:

$$
\mathrm{ADD}=\Sigma\left(\mathrm{C}_{\text {cereals }} \times \mathrm{IR}_{\text {cereals }} \times \mathrm{EF} \times \mathrm{ED} \times 10^{-3}\right) / \mathrm{AT} \times \mathrm{BW}
$$

where $\mathrm{C}_{\text {cereals }}$ is the PHE concentration in the investigated cereals $(\mathrm{mg} / \mathrm{kg} \mathrm{ww}) ; \mathrm{IR}_{\text {cereals }}$ is the intake rate of cereals (g/person per day); $\mathrm{EF}$ is the exposure frequency: $365 \mathrm{~d} / \mathrm{y}$; ED is the exposure duration: $30 \mathrm{y}$ for adults and six years for children [37]; AT is the averaging time in days: $\mathrm{ED} \times 365$ for non-carcinogens and $70 \mathrm{y} \times 365$ for carcinogens [46]; BW is body weight $(\mathrm{kg})$, as in Equation (4); and $10^{-3}$ is the unit conversion factor. 
The non-carcinogenic PHE risk values from dietary exposure were calculated with Equation (6), according to [43]:

$$
\mathrm{HQ}=\mathrm{ADD} / \mathrm{RfD}
$$

where $\mathrm{HQ}$ is the hazard quotient and RfD is the reference dose for a particular PHE.

The RfD values were set as follows (mg/kg bw per day): As $3.0 \times 10^{-4}, \mathrm{Cd} 1.0 \times 10^{-3}, \mathrm{Co} 3.0 \times$ $10^{-4}, \mathrm{Cu} 4.0 \times 10^{-2}, \mathrm{Hg} 3.0 \times 10^{-4}, \mathrm{Ni} 2.0 \times 10^{-2}, \mathrm{Sb} 4.0 \times 10^{-4}, \mathrm{Tl} 1.0 \times 10^{-5}$, and $\mathrm{Zn} 3.0 \times 10^{-1}$ [47].

The total non-carcinogenic risk (HQt) value for the investigated PHEs was calculated using Equation (7) according to [43]:

$$
\mathrm{HQt}=\mathrm{HQ}_{1}+\mathrm{HQ}_{2}+\ldots+\mathrm{HQ}_{\mathrm{n}}
$$

where HQ are the hazard quotient values for 1-n PHEs investigated in the study.

The carcinogenic risk values of PHEs from dietary exposure were calculated using Equation (8) according to [43]:

$$
\mathrm{CR}=\mathrm{ADD} \times \mathrm{SF}_{\mathrm{o}}
$$

where $\mathrm{CR}$ is the carcinogenic risk and $\mathrm{SF}_{\mathrm{o}}$ is the oral slope factor for a particular PHE.

Only As was considered to be a carcinogenic PHE in this study. There were no SF values available for other investigated elements at the time. The $\mathrm{SF}_{\mathrm{o}}$ for As was set to be equal to $1.5(\mathrm{mg} / \mathrm{kg}$ bw per day $)^{-1}$ [47]. The total carcinogenic risk value, as the sum of partial CR values, was not calculated because As was the only carcinogenic PHE considered in this study.

$\mathrm{The} \mathrm{Pb}$ risk of dietary exposure was calculated according to the margin of exposure (MOE) approach, as recommended by the European Food Safety Authority (EFSA) [48], using Equation (9) [49]:

$$
\mathrm{MOE}=\mathrm{BMDL} / \mathrm{DIR}
$$

where MOE is the margin of exposure value; BMDL is the benchmark dose (or the lower confidence limit), estimated at $1.2 \mu \mathrm{g} / \mathrm{kg}$ bw per day for adults and $0.6 \mu \mathrm{g} / \mathrm{kg}$ bw per day [17]; and DIR is the total amount of cereals consumed daily under the analyzed intake scenarios.

\section{Results}

\subsection{PHE Contents in Cereals}

In the six investigated species of cereals, the concentrations of $\mathrm{Cr}$ and Se were $<\mathrm{LOD}$, and thus, those two potentially harmful elements were excluded from further analysis. The detectable rates in cereal samples (\%) of remaining PHEs were the following: As 6.25\%, Cd 69.2\%, Co 6.25\%, Cu 100\%, $\mathrm{Hg} 46.8 \%$, Ni 76.9\%, $\mathrm{Pb} 30.8 \%$, Sb 76.9\%, $\mathrm{Tl} 38.5 \%$, and $\mathrm{Zn} \mathrm{100 \% .} \mathrm{The} \mathrm{concentrations} \mathrm{of} \mathrm{the} \mathrm{remaining}$ 10 PHEs in the investigated cereals (Table 3$)$ were contained within the following ranges $(\mathrm{mg} / \mathrm{kg} \mathrm{ww}$ ): As <LOD-0.013, Cd <LOD-0.291, Co <LOD-0.012, Cu 0.002-11.0, Hg <LOD-0.080, Ni <LOD-8.40, Pb $<$ LOD-12.0, $\mathrm{Sb}<$ LOD-0.430, Tl <LOD-0.160, and Zn 5.47-67.7. 
Table 3. Statistical parameters of potentially harmful elements (PHEs) in cereals.

\begin{tabular}{|c|c|c|c|c|c|c|c|c|}
\hline PHE & Statistical Parameters & Barley $(n=3)$ & Maize $(n=3)$ & Oat $(n=2)$ & Rye $(n=2)$ & Triticale $(n=2)$ & Wheat $(n=6)$ & Cereals $(n=18)$ \\
\hline \multirow{4}{*}{ As } & $\min$ & \multirow{4}{*}{ ND } & $<$ LOD & & & & & $<\mathrm{LOD}$ \\
\hline & mean \pm SD & & $0.004 \pm 0.002$ & & & & & $0.001 \pm 0.000$ \\
\hline & $\max$ & & 0.013 & $\mathrm{ND}$ & $\mathrm{ND}$ & $\mathrm{ND}$ & $\mathrm{ND}$ & 0.013 \\
\hline & 95th percentile & & 0.012 & & & & & 0.003 \\
\hline \multirow{4}{*}{$\mathrm{Cd}$} & $\min$ & 0.003 & $<\mathrm{LOD}$ & \multirow{4}{*}{ ND } & \multirow{4}{*}{ ND } & $<\mathrm{LOD}$ & $<\mathrm{LOD}$ & $<\mathrm{LOD}$ \\
\hline & mean $\pm \mathrm{SD}$ & $0.115 \pm 0.003$ & $0.006 \pm 0.003$ & & & $0.004 \pm 0.002$ & $0.017 \pm 0.004$ & $0.024 \pm 0.002$ \\
\hline & $\max$ & 0.291 & 0.011 & & & 0.008 & 0.043 & 0.291 \\
\hline & 95th percentile & 0.267 & 0.011 & & & 0.008 & 0.039 & 0.091 \\
\hline \multirow{4}{*}{ Co } & $\min$ & \multirow{4}{*}{ ND } & $<\mathrm{LOD}$ & & & & & $<\mathrm{LOD}$ \\
\hline & mean $\pm S D$ & & $0.004 \pm 0.002$ & & & & & $0.001 \pm 0.000$ \\
\hline & $\max$ & & 0.012 & ND & ND & ND & ND & 0.012 \\
\hline & 95th percentile & & 0.011 & & & & & 0.003 \\
\hline \multirow{4}{*}{$\mathrm{Cu}$} & $\min$ & 1.09 & 0.002 & 1.20 & 1.66 & 1.28 & 0.11 & 0.002 \\
\hline & mean $\pm S D$ & $1.42 \pm 0.01$ & $0.047 \pm 0.01$ & $4.56 \pm 0.01$ & $6.32 \pm 0.14$ & $1.42 \pm 0.06$ & $3.38 \pm 0.10$ & $2.93 \pm 0.08$ \\
\hline & $\max$ & 1.57 & 0.97 & 7.97 & 11.0 & 1.57 & 8.10 & 11.0 \\
\hline & 95th percentile & 1.55 & 0.91 & 7.64 & 10.5 & 1.55 & 7.44 & 5.88 \\
\hline \multirow{4}{*}{$\mathrm{Hg}$} & $\min$ & \multirow{4}{*}{ ND } & $<\mathrm{LOD}$ & & & & $<$ LOD & $<\mathrm{LOD}$ \\
\hline & mean $\pm \mathrm{SD}$ & & $0.002 \pm 0.001$ & & & & $0.032 \pm 0.011$ & $0.006 \pm 0.002$ \\
\hline & $\max$ & & 0.006 & ND & ND & ND & 0.080 & 0.080 \\
\hline & 95th percentile & & 0.006 & & & & 0.072 & 0.025 \\
\hline \multirow{4}{*}{$\mathrm{Ni}$} & $\min$ & 0.42 & $<$ LOD & 0.11 & $<$ LOD & $<$ LOD & $<\mathrm{LOD}$ & $<$ LOD \\
\hline & mean $\pm S D$ & $3.68 \pm 0.19$ & $0.819 \pm 0.086$ & $0.49 \pm 0.22$ & $0.74 \pm 0.08$ & $1.29 \pm 0.02$ & $2.22 \pm 0.04$ & $1.54 \pm 0.09$ \\
\hline & $\max$ & 8.40 & 1.484 & 0.86 & 1.47 & 2.58 & 5.86 & 8.40 \\
\hline & 95th percentile & 7.78 & 1.421 & 0.83 & 1.40 & 2.45 & 5.35 & 3.32 \\
\hline \multirow{4}{*}{$\mathrm{Pb}$} & $\min$ & $<\mathrm{LOD}$ & $<\mathrm{LOD}$ & $<$ LOD & $<$ LOD & \multirow{4}{*}{ ND } & $<$ LOD & $<\mathrm{LOD}$ \\
\hline & mean $\pm \mathrm{SD}$ & $2.17 \pm 0.02$ & $0.002 \pm 0.001$ & $6.00 \pm 0.03$ & $3.01 \pm 0.08$ & & $1.69 \pm 0.01$ & $2.15 \pm 0.02$ \\
\hline & $\max$ & 6.52 & 0.066 & 12.0 & 6.01 & & 6.76 & 12.0 \\
\hline & 95th percentile & 5.87 & 0.060 & 11.4 & 5.71 & & 5.75 & 5.25 \\
\hline
\end{tabular}


Table 3. Cont

\begin{tabular}{|c|c|c|c|c|c|c|c|c|}
\hline PHE & Statistical Parameters & Barley $(n=3)$ & Maize $(n=3)$ & Oat $(n=2)$ & Rye $(n=2)$ & Triticale $(n=2)$ & Wheat $(n=6)$ & Cereals $(n=18)$ \\
\hline \multirow{4}{*}{$\mathrm{Sb}$} & $\min$ & 0.047 & $<$ LOD & 0.016 & 0.170 & $<\mathrm{LOD}$ & $<\mathrm{LOD}$ & $<\mathrm{LOD}$ \\
\hline & mean $\pm S D$ & $0.099 \pm 0.006$ & $0.036 \pm 0.012$ & $0.071 \pm 0.012$ & $0.300 \pm 0.022$ & $0.011 \pm 0.006$ & $0.109 \pm 0.015$ & $0.104 \pm 0.012$ \\
\hline & $\max$ & 0.152 & 0.108 & 0.126 & 0.430 & 0.021 & 0.351 & 0.430 \\
\hline & 95th percentile & 0.147 & 0.097 & 0.120 & 0.417 & 0.020 & 0.311 & 0.252 \\
\hline \multirow{4}{*}{$\mathrm{Tl}$} & $\min$ & $<\mathrm{LOD}$ & $<$ LOD & $<$ LOD & $<\mathrm{LOD}$ & $<\mathrm{LOD}$ & $<$ LOD & $<$ LOD \\
\hline & mean $\pm S D$ & $0.004 \pm 0.002$ & $0.001 \pm 0.000$ & $0.080 \pm 0.001$ & $0.012 \pm 0.003$ & $0.007 \pm 0.001$ & $0.002 \pm 0.001$ & $0.018 \pm 0.001$ \\
\hline & $\max$ & 0.012 & 0.001 & 0.160 & 0.024 & 0.013 & 0.002 & 0.160 \\
\hline & 95th percentile & 0.011 & 0.001 & 0.152 & 0.023 & 0.011 & 0.002 & 0.063 \\
\hline \multirow{4}{*}{$\mathrm{Zn}$} & $\min$ & 33.5 & 5.47 & 43.2 & 51.2 & 38.8 & 21.2 & 5.47 \\
\hline & mean $\pm S D$ & $43.3 \pm 1.54$ & $7.40 \pm 1.16$ & $44.9 \pm 1.11$ & $59.4 \pm 2.01$ & $40.2 \pm 2.12$ & $42.3 \pm 0.54$ & $39.6 \pm 1.41$ \\
\hline & $\max$ & 50.1 & 8.39 & 46.7 & 67.7 & 41.5 & 60.4 & 67.7 \\
\hline & 95th percentile & 79.7 & 8.38 & 46.5 & 66.8 & 41.4 & 59.9 & 55.8 \\
\hline
\end{tabular}

LOD the limit of detection; ND $<$ LOD in all analyzed samples. 
The results of the PHE contents in barley revealed the following decreasing order: $\mathrm{Zn}>\mathrm{Ni}>\mathrm{Pb}>$ $\mathrm{Cu}>\mathrm{Cd}>\mathrm{Sb}>\mathrm{Tl}$. For maize, the decreasing order of PHE contents was as follows: $\mathrm{Zn}>\mathrm{Ni}>\mathrm{Cu}>$ $\mathrm{Sb}>\mathrm{Cd}>\mathrm{As}>\mathrm{Co}>\mathrm{Hg}>\mathrm{Pb}>\mathrm{Tl}$. In oat, the decreasing order of PHE contents was the following: $\mathrm{Zn}$ $>\mathrm{Pb}>\mathrm{Cu}>\mathrm{Ni}>\mathrm{Tl}>\mathrm{Sb}$. The decreasing order of PHE contents in rye was as follows: $\mathrm{Zn}>\mathrm{Cu}>\mathrm{Pb}>$ $\mathrm{Ni}>\mathrm{Sb}>\mathrm{Tl}$. For triticale, the decreasing order of PHE contents was the following: $\mathrm{Zn}>\mathrm{Cu}>\mathrm{Ni}>\mathrm{Sb}$ $>\mathrm{Tl}>\mathrm{Cd}$. For wheat, the decreasing order of PHE contents was as follows: $\mathrm{Zn}>\mathrm{Cu}>\mathrm{Ni}>\mathrm{Pb}>\mathrm{Sb}$ $>\mathrm{Hg}>\mathrm{Cd}>\mathrm{Tl}$. If any PHEs were not mentioned in the abovementioned sequences, their contents were $<$ LOD in a particular cereal. Considering essential elements, the decreasing order of $\mathrm{Cu}$ in the investigated cereal species was as follows: rye $>$ oat $>$ wheat $>$ barley $>$ triticale $>$ maize. In the case of $\mathrm{Zn}$, its decreasing order in the cereals was the following: rye $>$ oat $>$ barley $>$ wheat $>$ triticale $>$ maize. For nonessential elements, the decreasing order of particular PHEs in the investigated cereal species was as follows: As: maize $>$ barley $>$ oat $>$ rye $>$ triticale $>$ wheat; $\mathrm{Cd}$ : barley $>$ wheat $>$ maize $>$ triticale $>$ oat $>$ rye; Co: maize $>$ barley $>$ oat $>$ rye $>$ triticale $>$ wheat; Hg: wheat $>$ maize; Ni: barley $>$ wheat $>$ triticale $>$ maize rye $>$ oat; $\mathrm{Pb}$ : oat $>$ rye $>$ barley $>$ wheat $>$ maize $>$ triticale; $\mathrm{Sb}$ : rye $>$ wheat $>$ barley $>$ oat $>$ maize $>$ triticale; and Tl: oat $>$ rye $>$ triticale $>$ barley $>$ wheat $>$ maize.

In order to determine the analyzed cereal safety, the PHE content values were compared to the permissible levels stated in the EU regulation on maximum levels for certain contaminants in foodstuff [50]. The maximum allowable concentration values in cereals were specified for two investigated PHEs (mg/kg ww): $\mathrm{Pb} 0.20$ and $\mathrm{Cd} 0.10$ (for wheat: 0.20 ). The contents of $\mathrm{Pb}$ and $\mathrm{Cd}$ significantly exceeded the MAC values in wheat, oat, rye, and barley in the Ślaskie region. In the analyzed regions of southern Poland, the $\mathrm{Pb}$ and $\mathrm{Cd}$ contents in maize were much lower than the MAC values. The $\mathrm{Pb}$ and $\mathrm{Cd}$ contents in all the analyzed samples of triticale were $<\mathrm{LOD}$.

\subsection{Statistical Analysis}

PCA performed on the PHE concentrations in the investigated 18 cereal samples collected in southern Poland revealed three principal components (PCs), with eigenvalues higher than 1, which altogether explained $84.2 \%$ of the variance observed (Table 4). The first principal component (PC1) that accounted for $44.4 \%$ of variance had high $(>0.6)$ positive loading values of As and Co that were probably caused by the fact that As and Co contents were determined only in maize samples. On the other hand, the high negative loading values of $\mathrm{Cu}, \mathrm{Pb}, \mathrm{Sb}$, and $\mathrm{Zn}$ indicated that the lowest contents of those PHEs were stated in maize, as compared to the remaining investigated cereal species. The second principal component (PC2) explained $26.0 \%$ of variance and had negative loading values for $\mathrm{Ni}$ and $\mathrm{Cd}$, indicating a tendency of rye and oat to contain those PHEs. Moreover, the component could be correlated with easiness of $\mathrm{Cd}$ and $\mathrm{Ni}$ bioaccumulation in plants [51-54], because bioavailable concentrations of those PHEs were determined in soil [30]. The PCA ordination diagram for the first two PCs computed for PHE contents in cereals is presented in Figure S1. The third principal component (PC3) explained $13.8 \%$ of variance and had a high negative loading value for $\mathrm{Tl}$. That might be associated with other than geogenic sources of $\mathrm{Tl}$, such as from the atmospheric deposition as described in $[55,56]$, while a positive factor of the loading value for $\mathrm{Sb}$ might indicate mainly geogenic sources of $\mathrm{Sb}$, as the function of concentration in parent rocks and non-ferrous ores occurring in the soils where the cereals were cultivated [5,57]. In the cases of the remaining PHEs, their uptake by plants might come from both sources: as the effect of natural occurrence in soil and as the anthropogenic activity related to mining and processing $\mathrm{Zn}-\mathrm{Pb}$ and $\mathrm{Cu}$ ores.

HCA explored similarities between the contents of the investigated PHEs in the analyzed cereals. A hierarchical dendogram distinguished three similarity groups for the variables according to Sneath's criterion equal to $1 / 3 \mathrm{D}_{\max }$ (Figure S2). Cluster I could be associated with maize, as this cereal contained the highest contents of non-essential PHEs, i.e., As and $\mathrm{Co}$, and simultaneously the lowest contents of essential PHEs, i.e., $\mathrm{Cu}$ and $\mathrm{Zn}$. Cluster II could be associated with rye, as that cereal contained the highest proportions of $\mathrm{Zn}$ and $\mathrm{Cu}$ among the investigated cereals. Cluster III was connected with oat, triticale, wheat, and barley, because the investigated contents of PHEs were placed between the values 
observed in Clusters I and II. Standardized contents of PHEs in the regions of southern Poland were also presented on a color scale map (Figure S3) to show the geological background and soil impact on the PHE uptake. The map revealed that the highest quantities of $\mathrm{Pb}, \mathrm{Cd}, \mathrm{Ni}, \mathrm{Cu}, \mathrm{Tl}$, and $\mathrm{Zn}$, in comparison to other regions, were observed in the investigated cereals (except for maize) sampled in the Ślaskie region. The highest quantities of As and Co were observed in maize sampled in the Małopolskie region.

Table 4. Factor loading results obtained from the principal component analysis (PCA) for the cereals samples.

\begin{tabular}{cccc}
\hline PHEs & \multicolumn{3}{c}{ Varimax Rotated } \\
\cline { 2 - 4 } & PC1 & PC2 & PC3 \\
\hline $\mathrm{As}$ & $\mathbf{0 . 8 9 7}$ & 0.305 & 0.079 \\
$\mathrm{Cd}$ & -0.103 & $\mathbf{- 0 . 8 1 5}$ & -0.372 \\
$\mathrm{Co}$ & $\mathbf{0 . 8 9 7}$ & 0.305 & 0.079 \\
$\mathrm{Cu}$ & $\mathbf{- 0 . 8 2 7}$ & 0.443 & 0.317 \\
$\mathrm{Hg}$ & -0.122 & -0.314 & 0.498 \\
$\mathrm{Ni}$ & -0.281 & $\mathbf{- 0 . 9 3 7}$ & -0.146 \\
$\mathrm{~Pb}$ & $\mathbf{- 0 . 7 3 0}$ & 0.419 & -0.403 \\
$\mathrm{Sb}$ & $\mathbf{- 0 . 6 1 1}$ & 0.138 & 0.565 \\
$\mathrm{Tl}$ & -0.455 & $\mathbf{0 . 6 0 9}$ & $\mathbf{- 0 . 6 0 4}$ \\
$\mathrm{Zn}$ & $\mathbf{- 0 . 9 6 4}$ & -0.104 & 0.125 \\
\hline Eigenvalues & 4.44 & 2.60 & 1.38 \\
Explained variance \% & 44.4 & 26.0 & 13.8 \\
Cumulative variance \% & 44.4 & 70.4 & 84.2 \\
\hline
\end{tabular}

Factor loadings $>0.6$ or $<-0.6$ are shown in bold.

\subsection{Soil-To-Plant Transfer Indices}

Because plants stock up elements mainly from soil, transfer indices are used to determine the efficiency of the PHE uptake. In this study, bioaccumulation and bioconcentration indices were calculated for the investigated cereals cultivated in the regions of southern Poland. The numerical data of the distribution of the transfer-index calculated values were presented on the box-and-whisker chart in Figure 2. The bioconcentration coefficient $\left(\mathrm{BC}_{\mathrm{F} 1}\right)$ values were not calculated for $\mathrm{Hg}$ and $\mathrm{Pb}$, because those PHE contents in soil samples had been $\angle \mathrm{LOD}$ after the first step of the BCR extraction procedure. The bioconcentration coefficient $\left(\mathrm{BC}_{\mathrm{EDTA}}\right)$ values were also not calculated for $\mathrm{As}, \mathrm{Co}$, $\mathrm{Hg}$, Sb, or $\mathrm{Tl}$, because those PHEs had not been determined in soil samples after the $0.05 \mathrm{~mol} / \mathrm{dm}^{3}$ $\mathrm{Na}_{2}$ EDTA extraction procedure. Moreover, the bioaccumulation coefficient $\left(\mathrm{BA}_{\text {total }}\right)$ values were not calculated for $\mathrm{Cr}$ or Se, because $100 \%$ of the cereal samples indicated PHE concentrations of $<$ LOD. The calculated $\mathrm{BA}_{\text {total }}$ values were $<1$ (Figure 2a) in the cases of all cereals, which indicated that the investigated grains had no potential of PHE accumulation; however, the highest accumulation capacity was observed for $\mathrm{Tl}$ in oat $(\mathrm{BA}=0.8)$ and for $\mathrm{Hg}$ in wheat $(\mathrm{BA}=0.64)$. This could be associated with the concentration of those PHEs in soil, as well as with the ease of uptake from soil and transportation in plant tissues; however, grains are the most protected parts against harmful substances in the plant [5]. The calculated $\mathrm{BC}_{\text {EDTA }}$ values indicated the potential for PHE accumulation in cereals (BC values $>1$ ) (Figure 2c) for $\mathrm{Ni}>\mathrm{Zn}$ in barley, $\mathrm{Zn}>\mathrm{Cu}$ in oat and rye, and $\mathrm{Ni}>\mathrm{Zn}$ in wheat and triticale. The highest potential for PHE accumulation in cereals, on the basis of the calculated BC F1 values (Figure 2b), was observed for $\mathrm{Ni}>\mathrm{Sb}>\mathrm{Cu}$ in barley, $\mathrm{Ni}$ in maize, $\mathrm{Tl}>\mathrm{Cu}>\mathrm{Sb}$ in oat, $\mathrm{Cu}>\mathrm{Sb}>\mathrm{Tl}>\mathrm{Ni}$ in rye, $\mathrm{Ni}>$ $\mathrm{Cu}>\mathrm{Tl}$ for triticale, and $\mathrm{Cu}>\mathrm{Ni}>\mathrm{Sb}$ in wheat. The values of the calculated transfer factors are the function of PHEs in soils, and thus, they may vary in different locations; however, crops grown in the vicinity of mined non-ferrous metal ores should be monitored for potential contamination $[21,58]$. 


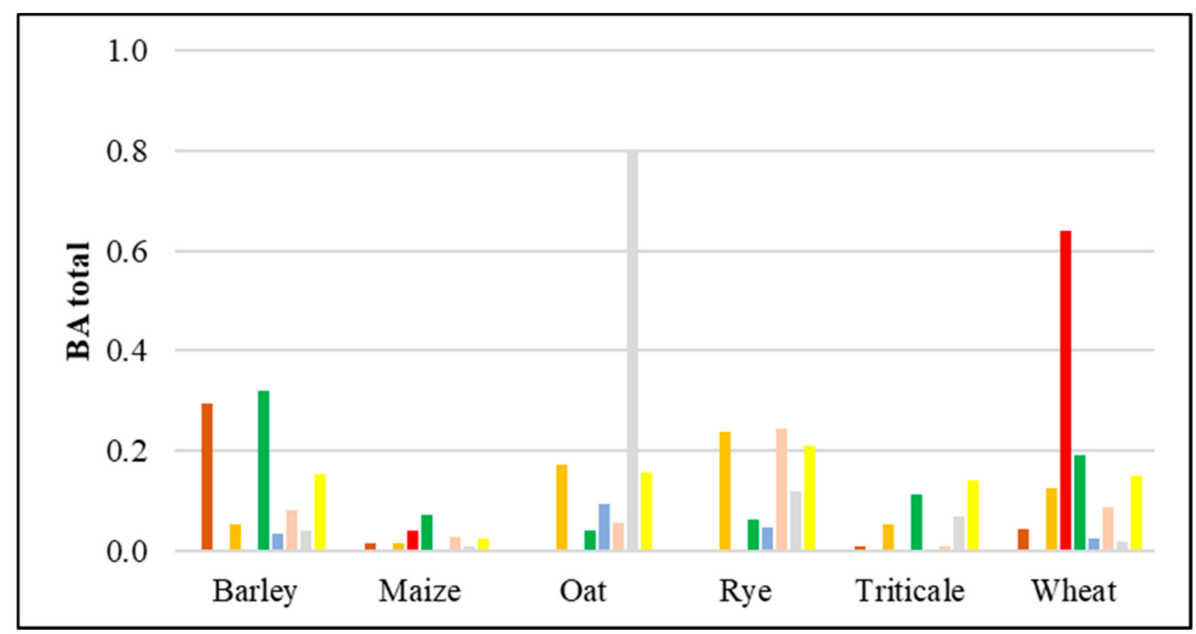

(a)

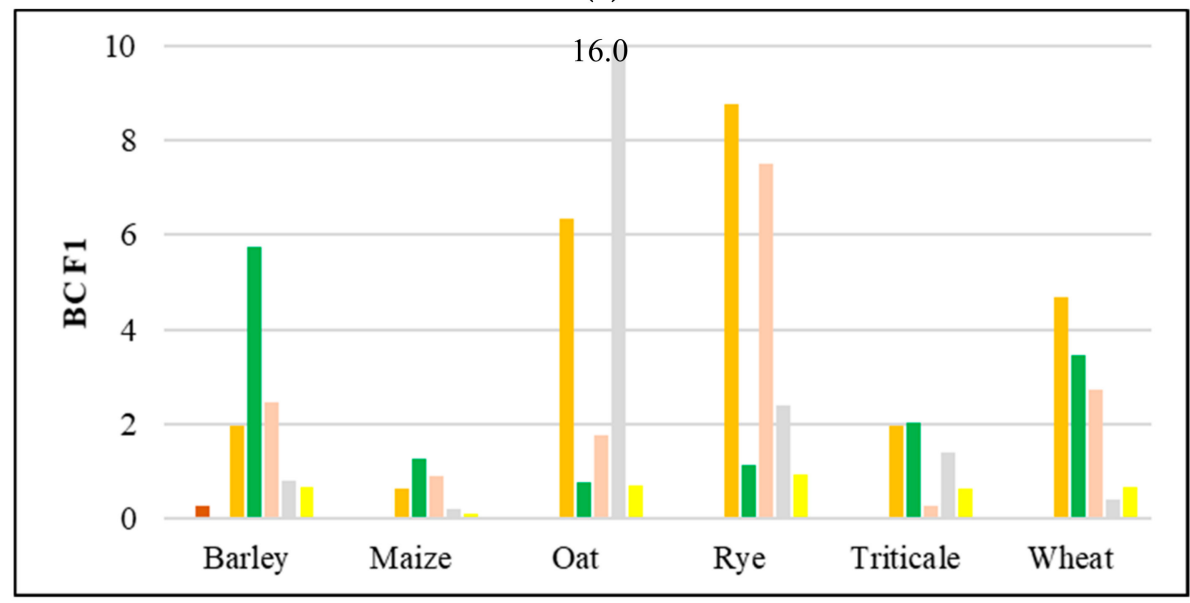

(b)

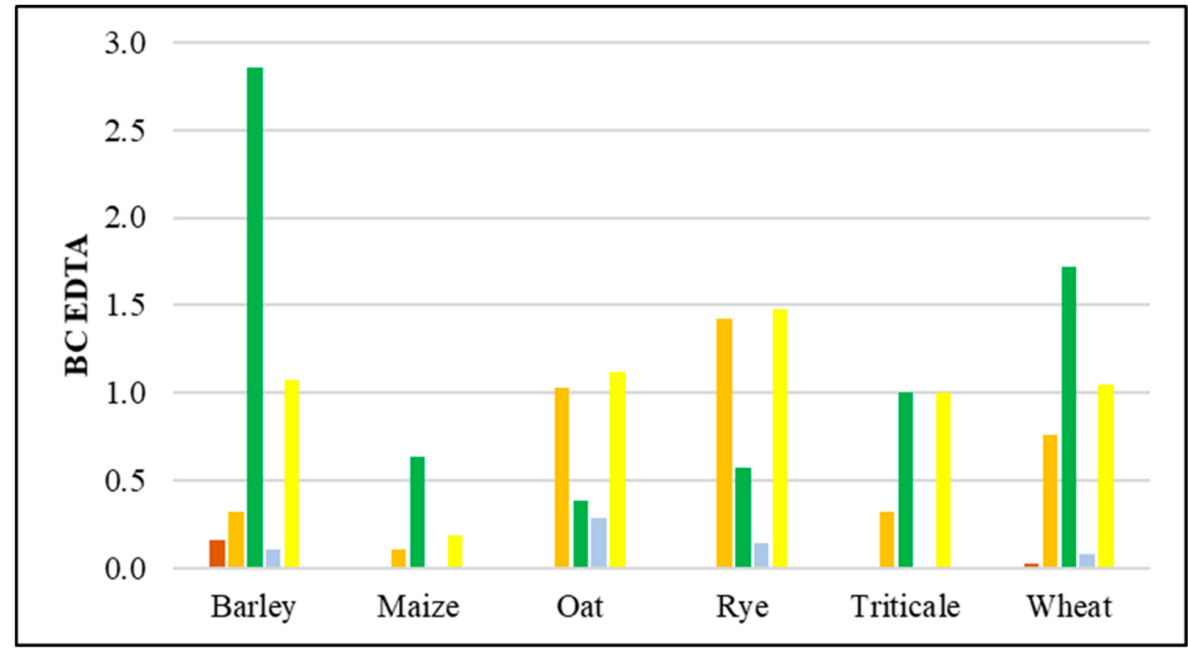

(c)

$\square$ As $\square \mathrm{Cd} \backsim \mathrm{Co} \square \mathrm{Cu} \square \mathrm{Hg} \square \mathrm{Ni} \square \mathrm{Pb} \backsim \mathrm{Sb} \square \mathrm{Tl} \backsim \mathrm{Zn}$

Figure 2. Soil-to-plant transfer indices for the investigated groups of cereals: (a) $\mathrm{BA}_{\text {total }}$-bioaccumulation coefficient, total PHE content; (b) $\mathrm{BC}_{\mathrm{F} 1}$ - bioconcentration coefficient, PHE content of the $\mathrm{F} 1$ fraction of the BCR sequential extraction; (c) $\mathrm{BC}_{\mathrm{EDTA}}$ - bioconcentration coefficient, PHE content $0.05 \mathrm{~mol} / \mathrm{dm}^{3}$ of the $\mathrm{Na}_{2}$ EDTA extraction. 


\subsection{Human Health Risk Assessment}

The results revealed the exceeded contents of $\mathrm{Pb}$ and $\mathrm{Cd}$ in reference to the MAC values. As to the remaining investigated PHEs, their safe concentrations in cereals were not specified. Moreover, the concentrations of PHEs in cereals are rather site specific and depend on the PHE concentration in soil. Finally, cereals are the main food consumed daily worldwide. Thus, considering the abovementioned reasons, the HHRA calculated in this study constituted an important part of our investigation.

\subsubsection{Daily Intake Rates}

According to available cereal consumption data [45], it was observed that a statistical Pole consumed $34.5 \mathrm{~g}$ of cereals daily (see Table 2). Because other statistical data were not available, the recommended daily intake rates of cereals by adults and children were adopted from the Australian Dietary Guidelines [4], equal to $585 \mathrm{~g}$ and $390 \mathrm{~g}$, respectively.

The calculated daily intake rate values of the consumed PHEs in six species of cereals were compared to the tolerable daily intakes of trace elements recommended by the Joint FAO/WHO Expert Committee on Food Additives (JECFA), World Health Organization, and United States Environmental Protection Agency guidelines. Using the provisional maximum tolerable daily intakes (PMTDI), the following values were adopted in this study (mg/kg bw per day): As 0.0021 [59], Cd 0.0008 [60], Co 0.0014 [61], $\mathrm{Cu} 0.5$ [62], Hg 0.0006 [63], Ni 0.005 [60], Sb 0.006 [64], Tl 0.00014 [65], and Zn 1 [62]. The PHE intake rates, calculated as a percentage of PMTDI (\%PMTDI) (Figure 3), revealed that, as regards the statistical daily consumption at the mean PHE concentrations for all six cereals, the mean PHE intake was as follows (as \% of PMTDI): As 0.0003, Cd 0.193, Co 0.0003, Cu 0.075, Hg 0.424, Ni 3.94, Pb $3.16, \mathrm{Sb} 0.23, \mathrm{Tl} 0.27$, and $\mathrm{Zn} 0.44$. Considering the recommended daily intakes of cereals, it was stated that PMTDIs were exceeded in wheat in children, in a decreasing order of PHEs as follows: $\mathrm{Ni}>\mathrm{Pb}>$ $\mathrm{Hg}>\mathrm{Zn}>\mathrm{Sb}>\mathrm{Cd}$. The above-described observations are the effect of the fact that wheat is the main cereal cultivated in Poland and that the chemical composition of agricultural soils in southern Poland depends strongly on the geological background abundant in PHEs, as well as on intense anthropogenic activities in that area [29].

\subsubsection{Non-Carcinogenic Risk of PHEs}

The target non-carcinogenic risk value was set to be equal to 1, according to the USEPA [43], as well as the Polish Regulation of the Minister of the Environment of 1 September 2016 on the conduct of the assessment of contamination of the surface of the Earth [66]. A statistical characterization of the calculated HQ for the respective cereals under the analyzed intake scenarios was presented in Figure 4. For particular PHEs, the target $\mathrm{HQ}=1$ value was exceeded in wheat in the decreasing order of PHEs as follows: $\mathrm{Sb}($ mean $\mathrm{HQ}=4.91)>\mathrm{Tl}(\mathrm{HQ}=1.87)>\mathrm{Ni}(\mathrm{HQ}=1.77)>\mathrm{Hg}(\mathrm{HQ}=1.62)>\mathrm{Zn}(\mathrm{HQ}$ $=1.59)>\mathrm{Cu}(\mathrm{HQ}=1.27)$ and rye: $\mathrm{Tl}(\mathrm{HQ}=1.85)>\mathrm{Sb}(\mathrm{HQ}=1.04)$. The total non-carcinogenic risk in the investigated cereals (as the sum of the HQ of single PHEs) revealed that risk was exceeded in wheat (mean $\mathrm{HQ}=13.3)$ and rye $(\mathrm{HQ}=3.44)$. For the remaining cereals, the total non-carcinogenic risk values were not exceeded and were ordered in the decreasing order of cereals as follows: barley $(\mathrm{HQ}=0.47)>$ oat $(\mathrm{HQ}=0.38)>$ maize $(\mathrm{HQ}=0.02)$. As regards the statistical daily consumption of all cereals in Poland, the total non-carcinogenic risk value of the mean PHE contents in cereals was equal to 0.58 , not exceeding the target risk value. At the 95th percentile of PHE contents in cereals, the total non-carcinogenic risk value was equal to 1.12 , slightly exceeding the target risk value. 

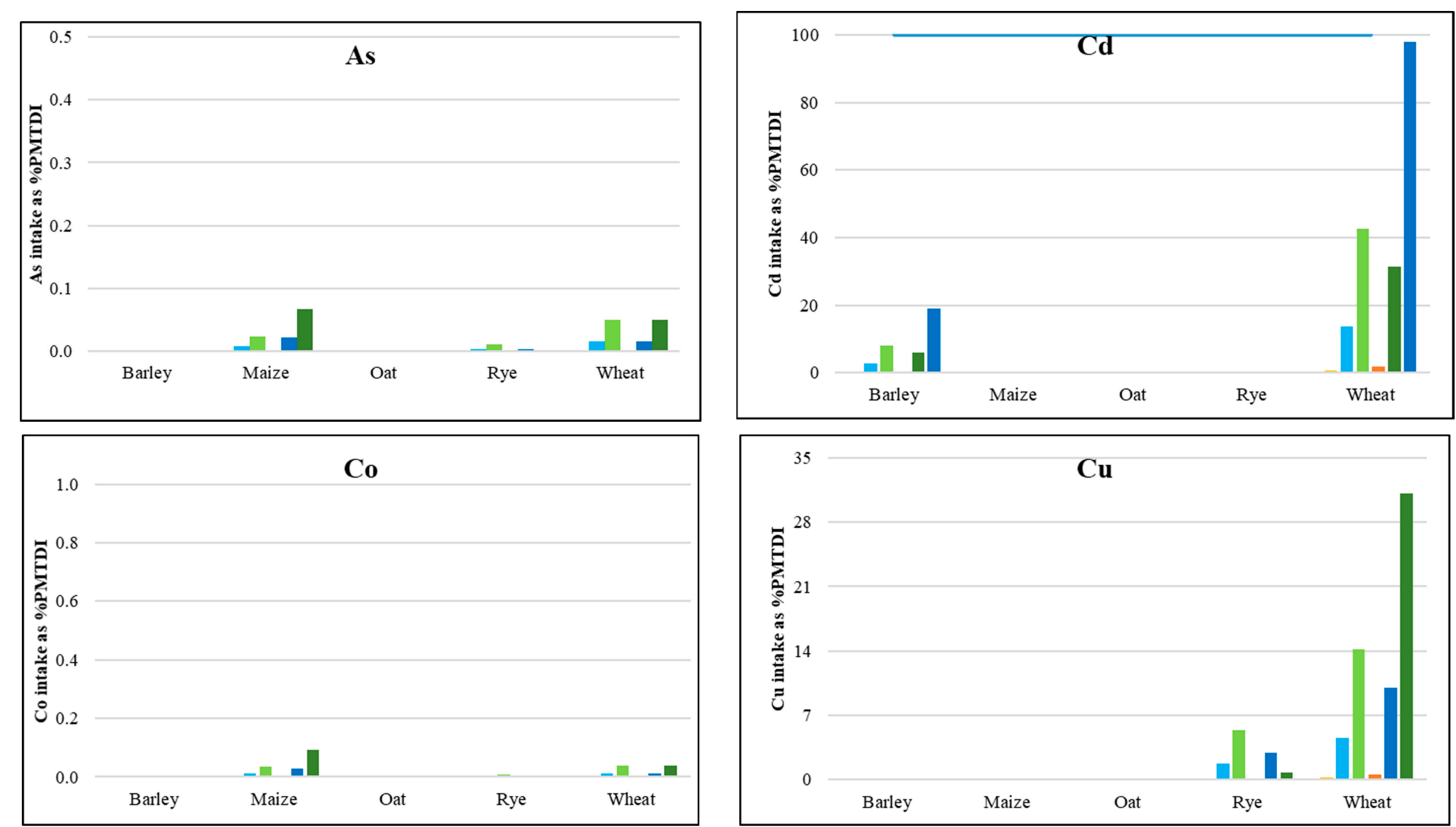

Figure 3. Cont. 

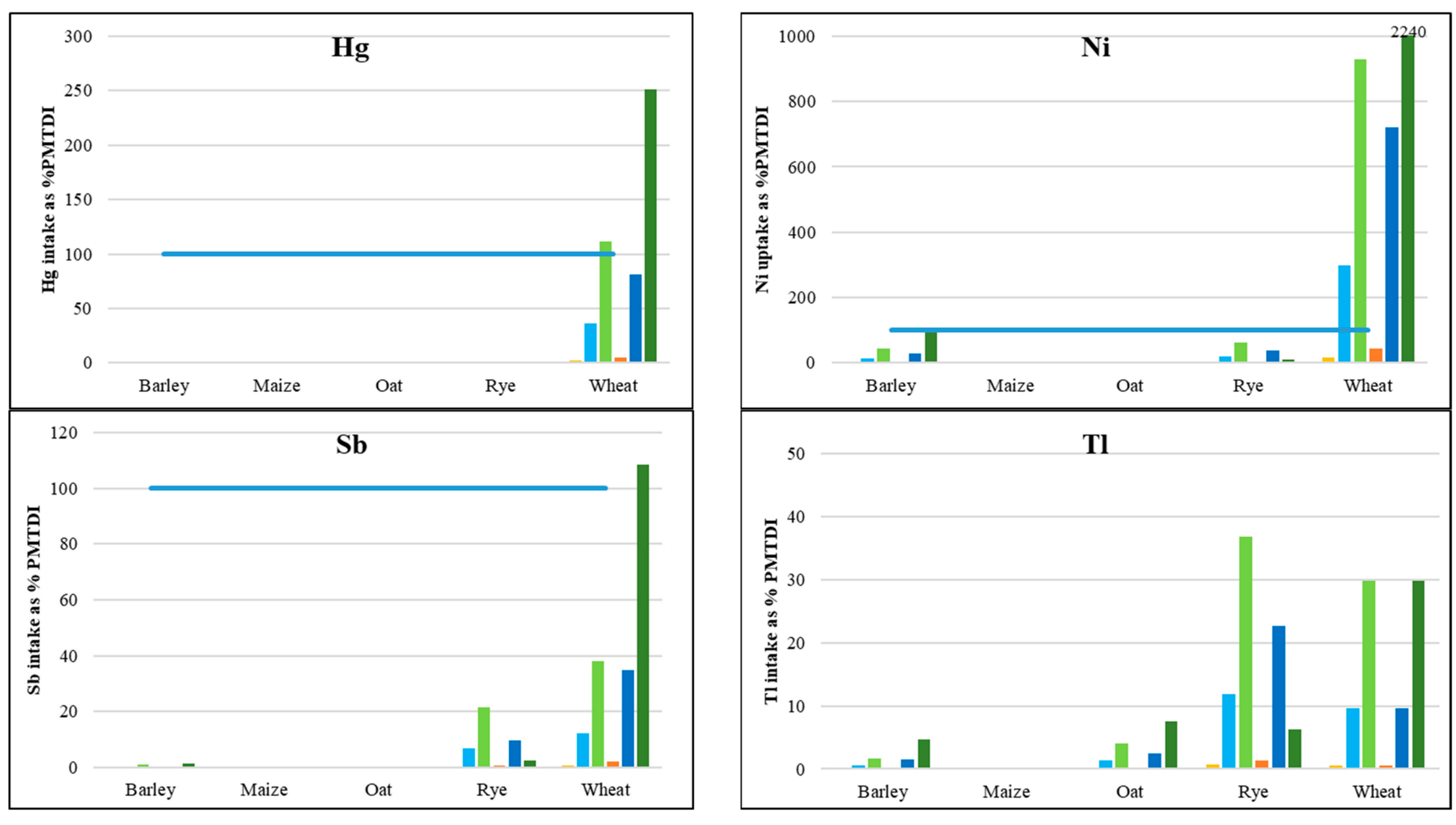

Figure 3. Cont. 


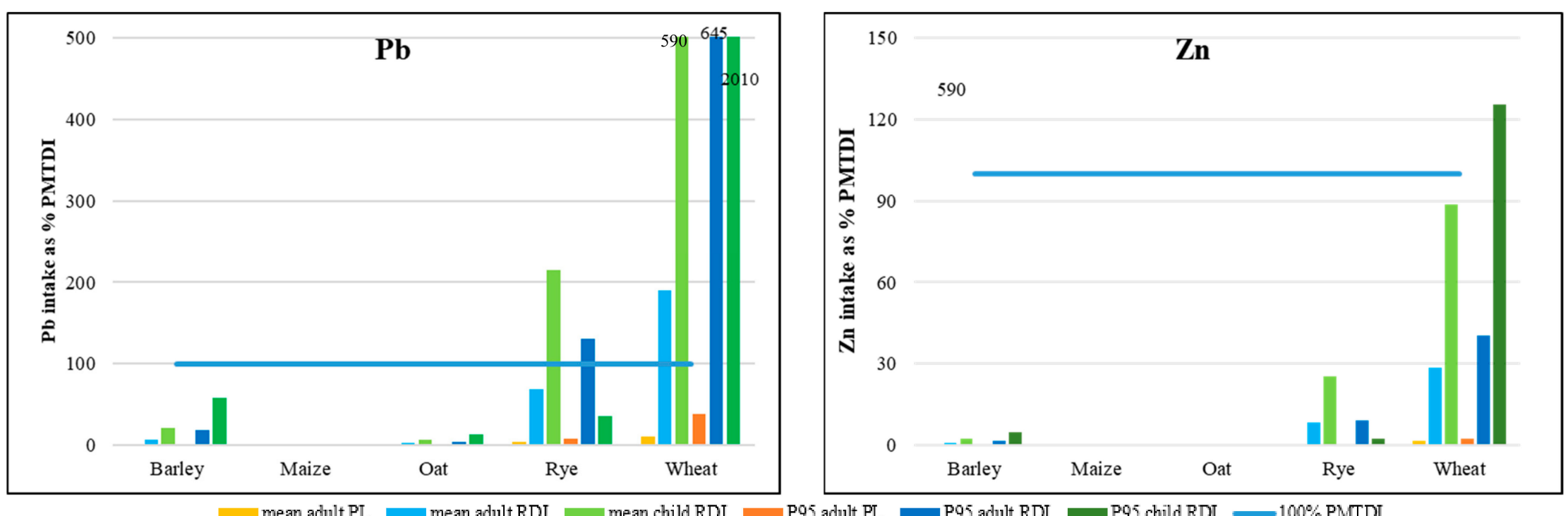

Figure 3. Daily intake rates of PHEs, with consumed cereals as a \% of provisional maximum tolerable daily intake (\%PMTDI); mean adult PL—daily intake rate for adults, statistical data for Poland [45], mean PHE concentration; mean adult RDI—recommended daily intake rate for adults [4], mean PHE concentration; mean child RDI—recommended daily intake rate for children [4], mean PHE concentration; P95 adult PL—intake rate for adults, statistical data for Poland [45], 95th percentile of PHE concentration; P95 adult RDI—recommended intake rate for adults [4], 95th percentile of PHE concentration; P95 child RDI—recommended intake rate for children [4], 95th percentile of PHE concentration. 

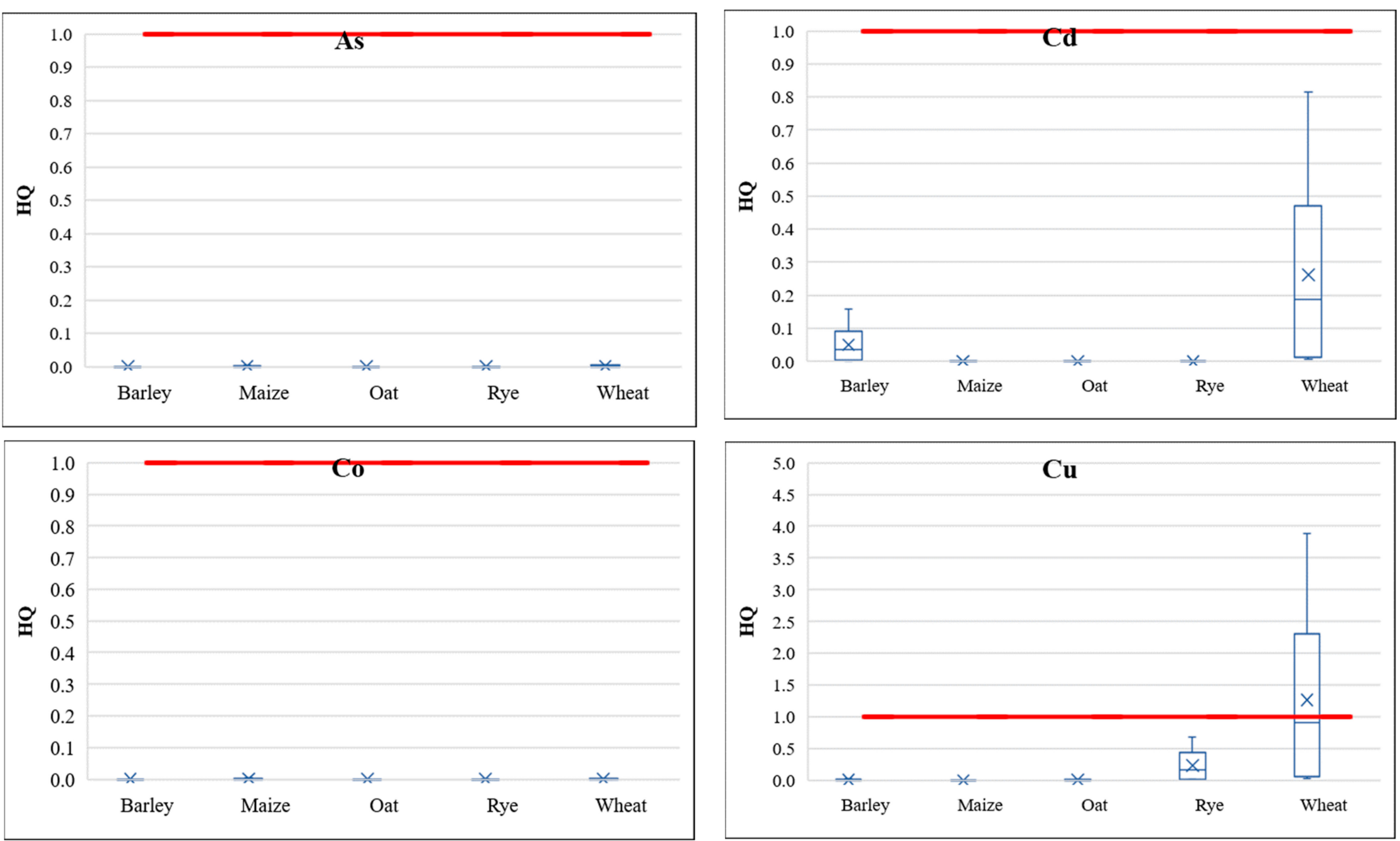

Figure 4. Cont 

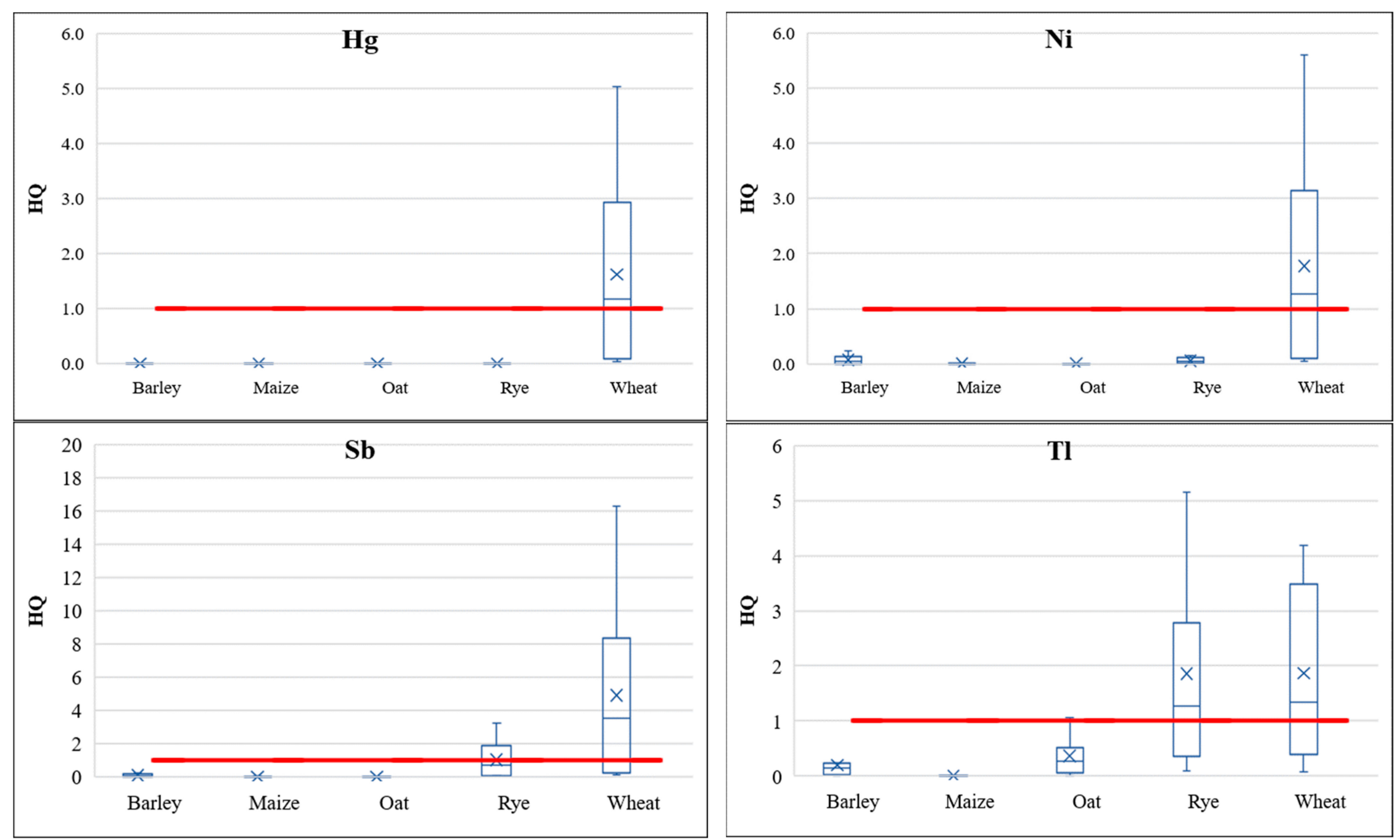

Figure 4. Cont. 

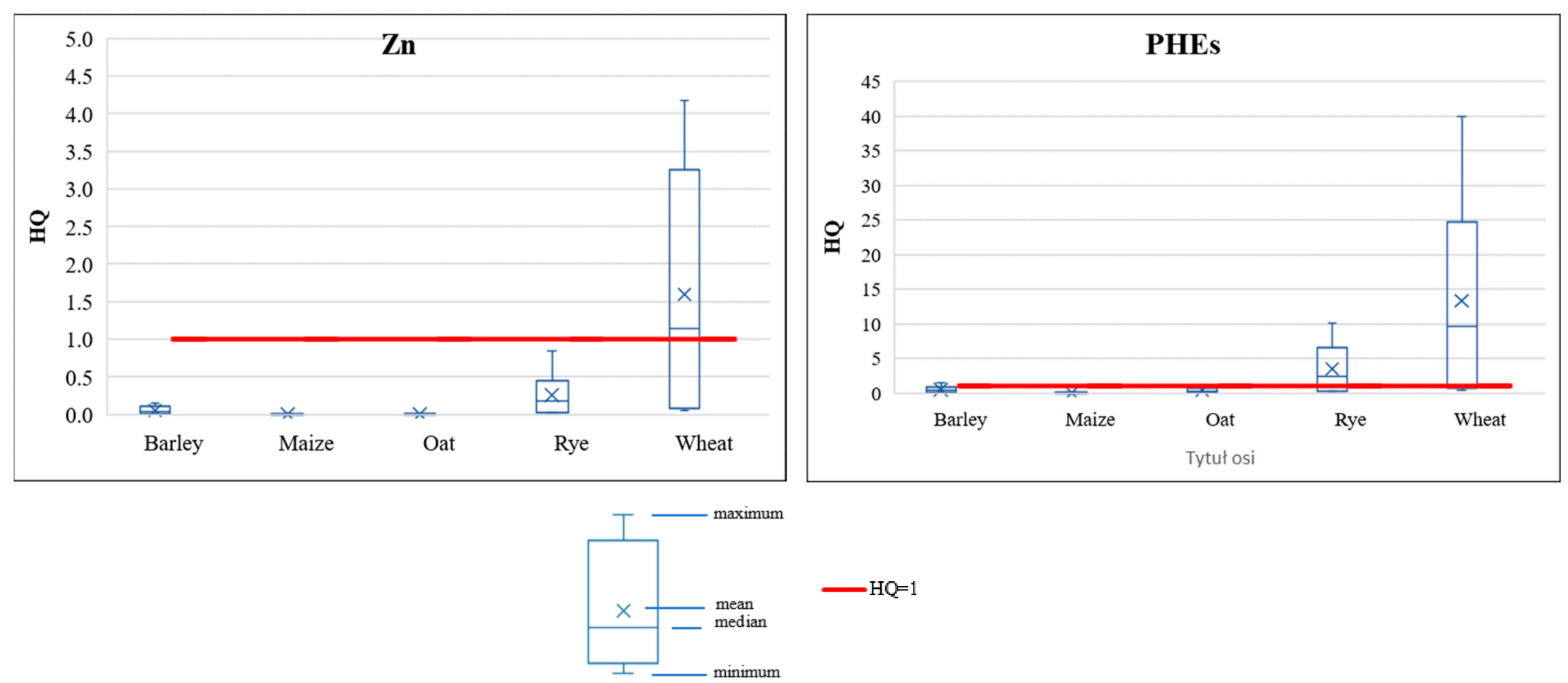

$-\mathrm{HQ}=1$

Figure 4. The non-carcinogenic risk values (HQ) of PHEs caused by cereal ingestion under the analyzed intake scenarios. 


\subsubsection{Carcinogenic Risk of PHEs}

The acceptable carcinogenic risk level was set to be equal to $1 \times 10^{-5}$, as defined in the Polish Regulation of the Minister of the Environment of 1 September 2016 on the conduct of the assessment of contamination of the surface of the Earth [66]. In this study, only As was investigated as carcinogenic according to the current knowledge of the SF values for chemical substances. Although, As contents were determined only in maize samples, for other cereals, halves of the LOD values were assigned (see Section 2.4). The statistical characterization of the calculated CR values of the investigated cereals, under the analyzed intake scenarios, is presented in Figure 5. The acceptable CR level of As was not exceeded in any of the analyzed intake scenarios. As regards the statistical daily consumption of all cereals in Poland, the carcinogenic risk value of the mean As content in cereals was equal to $5.1 \times 10^{-8}$, and at the 95th percentile of the As content in cereals, the carcinogenic risk value was equal to $7.8 \times$ $10^{-8}$, not exceeding any acceptable levels in either case.
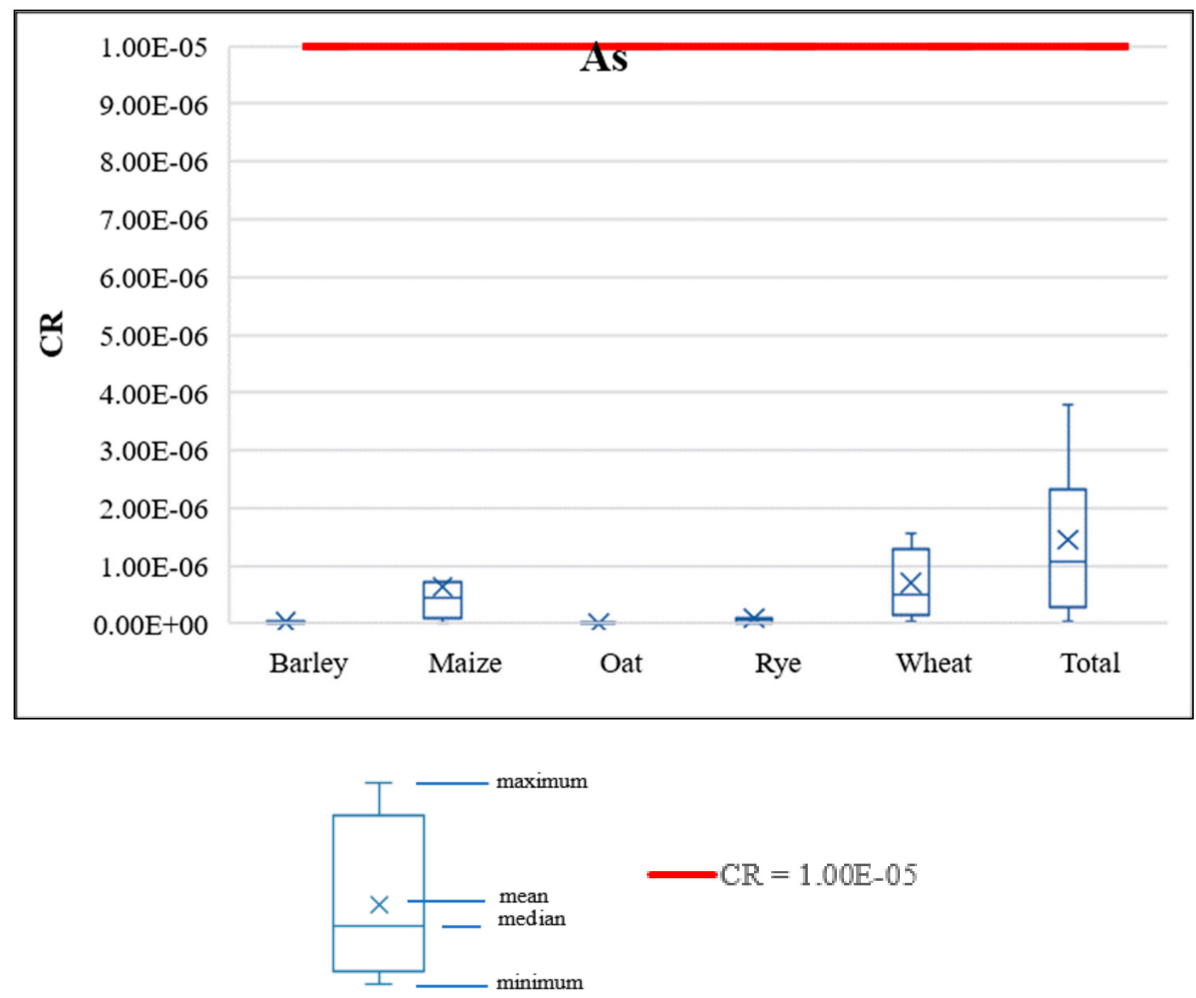

Figure 5. Carcinogenic risk $(\mathrm{CR})$ values for As under the analyzed cereal intake scenarios.

\subsubsection{Margin of Exposure to $\mathrm{Pb}$}

The BMDL values are used to determine the health risk from exposure to $\mathrm{Pb}$, although those values are not health-based guidance values but, rather, the levels below which health risk is considered to be acceptable low [17]. Thus, using the MOE approach, values $<1$ indicate high health risk, while values of $\mathrm{MOE}>1$ point at an acceptable low risk. Although, $\mathrm{Pb}$ contents were not determined in the triticale samples in this case, LOD values were assigned (see Section 2.4).

Considering the statistical daily consumption of cereals in Poland, the MOE value for the mean $\mathrm{Pb}$ content was equal to 1.27, indicating an acceptable low risk; however, at the 95th percentile of $\mathrm{Pb}$ content, the $\mathrm{MOE}$ value was equal to 0.42 , indicating a high risk of exposure to $\mathrm{Pb}$ (Table 5). Considering the recommended daily intakes of cereals by both adults and children, the MOE values were $<1$, indicating high risk arising from the $\mathrm{Pb}$ content in consumed cereals collected from the investigated regions of southern Poland. 
Table 5. Margin of exposure (MOE) values for $\mathrm{Pb}$ under the analyzed cereal intake scenarios.

\begin{tabular}{ccc}
\hline Cereals Intake Scenario & MOE (Mean Exposure) ${ }^{\mathbf{1}}$ & MOE (P95 Exposure) $^{\mathbf{2}}$ \\
\hline adult PL & 1.27 & 0.42 \\
adult RDI & 0.07 & 0.03 \\
child RDI & 0.01 & 0.005 \\
\hline
\end{tabular}

P95-95th percentile; adult PL—intake rate for adults, statistical data for Poland [45]; adult RDI—recommended daily intake rate for adults [4]; child RDI—recommended daily intake rate for children [4]; ${ }^{1}$ — calculated for mean $\mathrm{Pb}$ content in investigated cereals; ${ }^{2}$-calculated for $\mathrm{P} 95 \mathrm{~Pb}$ content in investigated cereals.

\subsubsection{Uncertainties in HHRA}

The value of calculated risk depended strongly on the respective intake rates. The risk values also depended strongly on the PHEs in the cereals cultivated in various regions of southern Poland, especially on the $\mathrm{Pb}$ contents in the Ślaskie region, and that fact caused overestimation of the risk values for all of southern Poland. When the recommended amounts of cereals for daily consumption were used, they also caused overestimation of the calculated risk values, because specific recommendations were rarely followed. Again, it has to be stated that food recommendations have to be based on environmental standards. Moreover, the completed HHRA assumed that the investigated cereals constituted $100 \%$ of the PHE intake, excluding other ingestion sources, as well as other exposure pathways, i.e., dermal contact or inhalation. Taking the above into consideration, it should be stated that the HHRA presented here is only part of the whole risk assessment that may be calculated, although the goal of the present investigation was to assess if there was a potential threat posed by the PHE content in the consumed cereals in the area of southern Poland.

\section{Discussion}

The contents of $\mathrm{Pb}, \mathrm{Ni}, \mathrm{Zn}$, and $\mathrm{Cd}$ measured in this study in six investigated species of cereals, were lower, and the $\mathrm{Cu}$ contents were at the same level in wheat $[1,12,18,19,22,23,26,27]$, maize $[1,12,22,27]$, and barley $[1,27]$. That may have been associated with anthropogenic pollution of the irrigating water and soil via industrial production, mining, or transportation [12]. Those differences might also be associated with the cultivated area, climate, cultivation practice, or cultivars [67]. The results obtained by Olero et al. [25] indicated higher concentrations of $\mathrm{As}, \mathrm{Cd}, \mathrm{Cr}$, and $\mathrm{Pb}$ in maize cultivated close to PHE emission sources, which were also reported by Shobha and Kalshetty [26] and Ibrahim et al. [68]. The concentrations of $\mathrm{Pb}, \mathrm{Zn}$, and $\mathrm{Cd}$ in barley were consistent with the results obtained by Eticha and Hymete [69], who reported that differences in metal contents in barley of different origins might be caused by differences in arable soil types, agrochemical treatment, and environmental pollution. The abovementioned results are in line with the observation that higher PHE concentrations in investigated cereals might be the consequence of the fact that $\mathrm{Zn}-\mathrm{Pb}[70,71]$ and $\mathrm{Cu}[72,73]$ ores are present in the geological background of soils in southern Poland. Moreover, the contents of $\mathrm{Pb}$ and $\mathrm{Cd}$ reported in wheat and barley grains sampled in northern Poland [74], where non-ferrous geological deposits do not occur, were lower than those identified in this study. In reference, the PHE contents determined in this study were contained within the concentration ranges of cereals cultivated in Poland reported by Kabata-Pendias [5]. Because $\mathrm{Cd}, \mathrm{Ni}, \mathrm{Zn}, \mathrm{Pb}$, and $\mathrm{Cu}$ were present in bioavailable forms in the investigated soils of southern Poland [30], that might cause PHE accumulation in the analyzed cereals. The results obtained by Kan et al. [75] indicated the highest $\mathrm{Zn}$ contents in rye, which were in line with the results obtained in the present study. However, for other PHEs, significant differences were reported among cereal cultivars affected by various agricultural practices, soil types, types of fertilizers, and plant protection products [75]. Large differences in PHE contents in various cereal species were also reported between European and Asian countries, while PHE levels were rather similar among European countries [3].

Moreover, it has to be underlined that the results discussed here were based on investigations performed on 18 cereal samples that might not be sufficiently representative. However, the main goal 
of the presented research was to assess the human health risk for consumers based on reliable PHE contents in cereals cultivated in the analyzed region of southern Poland.

In addition, the PCA was performed on the results from only 18 samples. Generally, the higher the number of samples, the more precise the results [76]; however, an analysis performed on 19 samples revealed correct results in $90 \%$ of cases [77]. Thus, the PCA results obtained might have shown some inadequacy due to the investigated number of samples.

Apart from the general use of soil-to-plant transfer indices and knowing that PHE translocation from roots to seeds in the plant is generally very limited [78], in this research the transfer factor values were calculated to assess if the PHE amounts taken up by cereals did not cause their accumulation in consumed seeds. The calculated BA were $<1$, indicating that total PHE contents in investigated soils [29] (Table S1) were not taken up by cereal seeds in elevated amounts [24]. However, the calculated $\mathrm{BC}$ values were $>1$ for $\mathrm{Ni}, \mathrm{Zn}$, and $\mathrm{Cu}$, as well as for $\mathrm{Tl}$ and $\mathrm{Sb}$. This could be caused by the presence of these PHEs in such high amounts in potentially bioavailable forms in soils [30] (Table S1) that after translocation in plants, their contents in seeds were significant. Moreover, $\mathrm{Ni}$ and $\mathrm{Zn}$ content in cereal might be caused by the presence of these PHEs in the commonly used mineral fertilizers in Poland. Mineral fertilizers commonly used in Poland were found to be abundant in Ni and $\mathrm{Zn}$, and elevated $\mathrm{Ni}$ contents were found in fertilizers with admixtures of grounded dolomite [79]. Organic manure used for fertilizing also contained significant amounts of $\mathrm{Ni}$ [80].

Considering the contents of PHEs in the investigated samples, limits of detection were used as the determined values and were lower than the limits of quantification (LOQ). However, as the main goal of the study was the health risk assessment, the PHE contents in the analyzed samples were necessary to obtain further results. Thus, as LOD values are the lowest concentrations likely to be reliably distinguished [81], this approach was intentionally used. It was recognized that the obtained results might have been unrepresentative; however, the performed research was done according to the parent rule of the conservative risk assessment principle.

The determination of the average daily intake is the critical point of the human health risk assessment analysis. In this research, permissible safe levels of PHEs in food were taken from the WHO as a global organization and from the USEPA as the author organization of the used methodology. However, there is not always compliance among health institutions with respect to the safe limits of PHE intakes in food. Moreover, the safe limits of food contaminants often change as new evidence for health safety is obtained. The European Food Safety Authority Panel on Contaminants in the Food Chain (CONTAM Panel) revealed that values established by the Joint FAO/WHO Expert Committee on Food Additives (JECFA) are no longer appropriate. For As, a range of benchmark doses at a lower confidence limit of $1 \%$ extra risk $\left(\mathrm{BMDL}_{01}\right)$ with values between 0.3 and $8 \mu \mathrm{g} / \mathrm{kg}$ body weight per day was identified [82]. For inorganic $\mathrm{Hg}$, the EFSA CONTAM Panel stayed in line with JECFA, establishing a tolerable weekly intake for inorganic mercury of $4 \mu \mathrm{g} / \mathrm{kg}$ bw [83]. For Ni, the EFSA CONTAM panel derived a tolerable daily intake of $2.8 \mu \mathrm{g} \mathrm{Ni} / \mathrm{kg}$ bw from a lower $95 \%$ confidence limit for a benchmark dose at $10 \%$ extra risk (BMDL10) of $0.28 \mathrm{mg} \mathrm{Ni} / \mathrm{kg}$ bw [84]. For Cd, the EFSA CONTAM panel nominated a tolerable weekly intake of $2.5 \mu \mathrm{g} / \mathrm{kg}$ bw to ensure sufficient protection of all consumers [85]. For Pb, the EFSA CONTAM panel concluded that the safe intake value was no longer appropriate, and as there was no evidence for a threshold for a number of critical endpoints, it was not appropriate to derive a permissible tolerable weekly intake (PTWI) [48]. In the case of essential PHEs, such as Cu [86] and Zn [87], the EFSA Panel on Dietetic Products, Nutrition, and Allergies (NDA) proposed daily adequate intakes depending on age and sex. Thus, comparisons of results of different HHRA investigations must be taken with caution, as they may lead to significantly different interpretations of risk values.

\section{Conclusions}

The potentially harmful element contents in six cereal species cultivated on arable soils in southern Poland were investigated, and in reference to that, the human health risk implications were assessed 
as well. The contents of $\mathrm{Pb}$ and $\mathrm{Cd}$ significantly exceeded the MAC values in wheat, oat, rye, and barley in the Ślaskie region. In maize, $\mathrm{Pb}$ and $\mathrm{Cd}$ contents were much lower than the MAC values. The bioaccumulation coefficient, calculated for the total PHE content in soil, indicated that cereals had no potential of PHE accumulation in seeds. The PHE daily intake rates of all six cereals based on the statistical daily consumption ranged from hundredths of a percent to a maximum of several percentage points of the permissible maximum tolerable daily intake. The calculated non-carcinogenic risk values for all the investigated PHEs were exceeded only in wheat $(H Q=13.3)$ and rye $(H Q=3.44)$. As regards the statistical daily consumption of cereals in Poland, the total non-carcinogenic risk was at the acceptable level according to the mean PHE contents. The acceptable cancer risk level of As was not exceeded under any of the intake scenarios; however, only the HHRA for As contents in maize was analyzed. Risk arising from $\mathrm{Pb}$ content in consumed cereals defined based on the MOE approach was acceptable low. The presented research proved that, even though the permissible levels of PHEs in soils have not been exceeded, monitoring of particular food crops is pivotal because the environment is getting more and more polluted, and all factors affecting the soil-to-plant transfer remain not fully known in the context of further consumption by animals and humans. Thus, it would be recommended to extend the current research on a larger scale with a statistically significant number of samples and computational modeling of the HHRA analysis to verify the reliability of the obtained results.

Supplementary Materials: The following are available online at http://www.mdpi.com/1660-4601/17/5/1674/s1, Table S1: PHE contents in arable soils in southern Poland (based on [1,2]) used for soil-to-plant transfer indices in this study, Figure S1. Ordination diagram of PCA, computed for the PHE contents in cereals samples. Figure S2. Dendogram of PHEs in cereals, according to Sneath's criteria. Figure S3. The color-scale map of standardized PHE contents in cereals species.

Funding: This research was funded by the AGH University of Science and Technology, Dean's grant number 15.11.140.357 and Statutory Research grant number 11.11.140.199. The Article Processing Charge was funded by the AGH University of Science and Technology.

Conflicts of Interest: The author declares no conflict of interest. The funders had no role in the design of the study; in the collection, analyses, or interpretation of data; in the writing of the manuscript, or in the decision to publish the results.

\section{References}

1. Hussain, S.; Rengel, Z.; Qaswar, M.; Amir, M.; Zafar-ul-Hye, M. Arsenic and heavy metal (cadmium, lead, mercury and nickel) contamination in plant-based foods. In Plant and Human Health. Volume 2 Phytochemistry and Molecular Aspects; Ozturk, M., Hakeem, K.R., Eds.; Springer: Cham, Switzerland, 2019; Volume 2, pp. 447-490.

2. Shewry, P.R.; Hey, S.J. The contribution of wheat to human diet and health. Food Energy Secur. 2015, 4, 178-202. [CrossRef]

3. Jākobsone, I.; Kāntane, I.; Zute, S.; Jansone, I.; Bartkevičs, V. Macro-elements and trace elements in cereal grains cultivated in Latvia. Proc. Latv. Acad. Sci. Sect. B 2015, 69, 152-157. [CrossRef]

4. National Health and Medical Research Council. Australian Dietary Guidelines; National Health and Medical Research Council, N55: Canberra, Australia, 2013.

5. Kabata-Pendias, A. Trace Elements in Soils and Plants, 4th ed.; CRC Press: Boca Raton, FL, USA, 2011.

6. Singh, R.; Gautam, N.; Mishra, A.; Gupta, R. Heavy metals and living systems: An overview. Indian J. Pharmacol. 2011, 43, 246-253. [CrossRef] [PubMed]

7. Ghuniem, M.M.; Khorshed, M.A.; Souaya, E.R. Method validation for direct determination of some trace and toxic elements in soft drinks by inductively coupled plasma mass spectrometry. Int. J. Environ. Chem. 2019, 99, 515-540. [CrossRef]

8. Khalil, M.M.H.; Khorshed, M.A.; Ghuniem, M.M. Development of analytical method for determination of some essential and toxic elements in some canned and homemade babyfood samples in Giza. Res. J. Chem. Environ. Sci. 2016, 4, 1-7.

9. Bini, C.; Bech, J. PHEs, Environment and Human Health. In Potentially Harmful Elements in the Environment and the Impact on Human Health; Springer: Dordrecht, The Netherlands, 2014. 
10. Baker, D.; Karalliedde, L.; Murray, V.; Maynard, R.; Parkinson, N.H.T. Essentials of Toxicology for Health Protection: A Handbook for Field Professionals, 2nd ed.; Oxford University Press: Oxford, UK, 2012.

11. El-Kady, A.A.; Abdel-Wahhab, M.A. Occurrence of trace metals in foodstuffs and their health impact. Trends Food Sci. Techol. 2018, 75, 36-45. [CrossRef]

12. Pirsaheb, M.; Fattahi, N.; Sharafi, K.; Khamotian, R.; Atafar, Z. Essential and toxic heavy metals in cereals and agricultural products marketed in Kermanshah, Iran, and human health risk assessment. Food Addit. Contam. B 2016, 9, 15-20. [CrossRef]

13. International Agency for Research on Cancer. A Review of Human Carcinogens: Arsenic, Metals, Fibres, and Dusts: Chromium (VI) Compounds. IARC Monographs Vol. 100C-9. International Agency for Research on Cancer (IARC). 2012. Available online: http://monographs.iarc.fr/ENG/Monographs/vol100C/mono100C9.pdf (accessed on 10 February 2019).

14. Kelepertzis, E.; Paraskevopoulou, V.; Argyraki, A.; Fligos, G.; Chalkiadaki, O. Evaluation of single extraction procedures for the assessment of heavy metal extractability in citrus agricultural soil of a typical Mediterranean environment (Argolida, Greece). J. Soils Sediments 2015, 15, 2265-2275. [CrossRef]

15. Klimek-Kopyra, A.; Baran, A.; Zajac, T.; Kulig, B. Effects of heavy metals from polluted soils on the roots and nodules formation. Bulg. J. Agric. Sci. 2015, 21, 295-299.

16. Šukalić, A.; Ahmetović, N.; Mačkić, S.; Leto, A.; Džubur, A.; Antunović, B. Human Health Risk Assessment of Heavy Metals from the Agricultural Soil in South Herzegovina. Agric. Conspec. Sci. 2018, 83, 45-50.

17. Wang, M.; Liang, B.; Zhang, W.; Chen, K.; Zhang, Y.; Zhou, H.; Cheng, Y.; Liu, H.; Zhong, X.; Li, Y.; et al. Dietary lead exposure and associated health risks in Guangzhou, China. Int. J. Environ. Res. Public Health 2019, 16, 1417. [CrossRef] [PubMed]

18. Ahmed, M.K.; Shaheen, N.; Islam, M.S.; Habibullah-Al-Mamun, M.; Islam, S.; Banu, C.P. Trace elements in two staple cereals (rice and wheat) and associated health risk implications in Bangladesh. Environ. Monit. Assess. 2015, 187, 326. [CrossRef] [PubMed]

19. Ali, M.H.H.; Al-Qahtani, K.M. Assessment of some heavy metals in vegetables, cereals and fruits in Saudi Arabian markets. Egypt. J. Aquat. Res. 2012, 38, 31-37. [CrossRef]

20. Ali, J.; Khan, S.; Khan, A.; Waqas, M.; Nasir, M.J. Contamination of soil with potentially toxic metals and their bioaccumulation in wheat and associated health risk. Environ. Monit. Asses. 2020, 192, 138. [CrossRef]

21. Compaore, W.F.; Dumoulin, A.; Rousseau, D.P.L. Trace element content in cereals from a gold mining site in Burkina Faso and intake risk assessment. J. Environ. Manag. 2019, 248, 109292. [CrossRef]

22. Islam, M.S.; Ahmed, M.K.; Habibullah-Al-Mamun, M. Heavy metals in cereals and pulses: Health implications in Bangladesh. J. Agric. Food Chem. 2014, 62, 10828-10835. [CrossRef]

23. Kulkarni, C.P. Assessment of heavy metals in vegetables and cereals collected from local market, Mumbai. Int. J. Food Sci. Nutr. 2017, 2, 71-74.

24. Mao, C.; Song, Y.; Chen, L.; Ji, J.; Li, J.; Yuan, X.; Yang, Z.; Ayoko, G.A.; Frost, R.L.; Theiss, F. Human health risk of heavy metals in paddy rice based on transfer characteristics of heavy metals from soil to rice. Catena 2019, 175, 339-348. [CrossRef]

25. Olero, J.N.K.; Simiyu, G.M.; Kipkorir, E.C.; Wakhisi, J. Selected Heavy Metal Levels in Cereals in Fluorspar Mining Belt, Elgeyo Marakwet County in Kenya. Afr. Environ. Rev. J. 2018, 3, 65-73.

26. Shobha, N.; Kalshetty, B.M. Assessment of heavy metals in green vegetables and cereals collected from Jamkhandi local market, Bagalkot, India. Rasayan J. Chem. 2017, 10, 124-135.

27. Tegegne, W.A. Assessment of some heavy metals concentration in selected cereals collected from local markets of Ambo City, Ethiopia. J. Cereals Oilseeds 2015, 6, 8-13.

28. Houlihan, J.; Brody, C. What's in My baby's Food? Healthy Babies Bright Futures and Virginia Organizing, October 2019. Available online: https://www.healthybabyfood.org/sites/healthybabyfoods.org/files/2019-10/ BabyFoodReport_FULLREPORT_ENGLISH_R5b.pdf (accessed on 30 January 2020).

29. Gruszecka-Kosowska, A.; Baran, A.; Wdowin, M.; Mazur-Kajta, K.; Czech, T. The contents of the potentially harmful elements in the arable soils of southern Poland, with the assessment of ecological and health risks: A case study. Environ. Geochem. Health 2020, 42, 419-442. [CrossRef] [PubMed]

30. Gruszecka-Kosowska, A.; Baran, A.; Mazur-Kajta, K.; Czech, T. Geochemical fractions of the agricultural soils of southern Poland and the assessment of the potentially harmful element mobility. Minerals 2019, 9, 674. [CrossRef]

31. FAO. Fertilizers Use by Crop in Poland; Food and Agriculture Organization of the UN: Rome, Italy, 2003. 
32. Statistics Poland. Means of Production in Agriculture in the 2018/19 Farming Year. Statistical Information; Statistics Poland: Warsaw, Poland, 2020.

33. Gruszecka-Kosowska, A. Potentially harmful element concentrations in the vegetables cultivated on arable soils, with human health risk implications. Int. J. Environ. Res. Public Health 2019, 16, 4053. [CrossRef] [PubMed]

34. Gruszecka-Kosowska, A. Human health risk assessment and potentially harmful element contents in the fruits cultivated in the southern Poland. Int. J. Environ. Res. Public Health 2019, 16, 5096. [CrossRef] [PubMed]

35. Method 6020B: Inductively Coupled Plasma-Mass Spectrometry. Revision 2; USEPA: Washington, DC, USA, 1998. Available online: https:/www.epa.gov/sites/production/files/2015-12/documents/6020b.pdf (accessed on 15 January 2019).

36. Polish Committee for Standardization. Water Quality-Use of Inductively Induced Plasma Mass Spectrometry (ICP-MS)_Part 2: Determination of 62 Elements; PN-EN ISO 17294-2; Polish Committee for Standardization: Warsaw, Poland, 2006.

37. Exposure Factors Handbook: 2011 Edition; EPA/600/R-09/052F, US Environmental Protection Agency; National Center for Environmental Assessment: Washington, DC, USA, 2011. Available online: http://ofmpub.epa. gov/eims/eimscomm.getfile?p_download_id=522996 (accessed on 3 March 2019).

38. Polish Committee for Standardization. Water Quality_Induced Plasma Mass Spectrometry (ICP-MS)—Part 1: General Guidelines; PN-EN ISO 17294-1; Polish Committee for Standardization: Warsaw, Poland, 2007.

39. Polish Committee for Standardization. Water Quality_Determination of Selected Elements by Inductively Coupled Plasma Optical Emission Spectrometry (ICP-OES); PN-EN ISO 11885:2009; Polish Committee for Standardization: Warsaw, Poland, 2009.

40. WHO. GEMS/Food-EURO Second Workshop on Reliable Evaluation of Low-Level Contamination of Food, Proceedings of the Report on a Workshop in the Frame of GEMS Food-EURO, Kulmbach, Germany, 26-27 May 1995; WHO: Geneva, Switzerland, 1995.

41. Inácio, M.; Neves, O.; Pereira, V.; da Silva, E.F. Levels of selected potential harmful elements (PHEs) in soils and vegetables used in diet of the population living in the surroundings of the Estarreja Chemical Complex (Portugal). Appl. Geochem. 2014, 44, 38-44. [CrossRef]

42. Wang, G.; Su, M.Y.; Chen, Y.H.; Lin, F.F.; Luo, D.; Gao, S.F. Transfer characteristic of cadmium and lead from soil to the edible parts of six vegetable species in southeastern China. Environ. Pollut. 2006, 144, 127-135. [CrossRef]

43. Risk Assessment Guidance for Superfund, Vol. 1: Human Health Evaluation Manual, Part A.; Interim Final; Office of Emergency and Remedial Response. US Environmental Protection Agency: Washington, DC, USA, 1989. Available online: https://www.epa.gov/sites/production/files/2015-09/documents/rags_a.pdf (accessed on 11 April 2019).

44. WHO. Dietary Exposure Assessment of Chemicals in Food; Report of Joint FAO/WHO Consultation; WHO Library: Annapolis, MD, USA, 2005.

45. Łopaciuk, W. Cereals Market State and Perspectives. In No 56. Institute of Agricultural and Food Economics-National Research Institute; IERiGŻ-PIB: Warsaw, Poland, 2019.

46. Risk Assessment Guidance for Superfund, Vol. 3: Part A, Process for Conducting Probabilistic Risk Assessment; Office of Emergency and Remedial Response, US Environmental Protection Agency: Washington, DC, USA, 2001. Available online: https://www.epa.gov/sites/production/files/2015-09/documents/rags3adt_complete.pdf (accessed on 11 April 2019).

47. Regional Screening Level (RSL) Summary Table ( $T R=10-6, H Q=1)$, April 2019. US Environmental Protection Agency: Washington DC, USA, 2019. Available online: https://semspub.epa.gov/src/document/HQ/199432 (accessed on 12 June 2019).

48. EFSA. Scientific Opinion on Lead in Food; EFSA Panel on Contaminants in the Food Chain (CONTAM); European Food Safety Authority (EFSA): Parma, Italy, 2010; Volume 8, p. 151.

49. European Food Safety Authority. Opinion of the scientific committee on a request from EFSA related to a harmonised approach for risk assessment of substances which are both genotoxic and carcinogenic. Eur. Food Saf. Auth. J. 2005, 10, 282.

50. EC 1881/2006. Commission regulation (EC) No 1881/2006 of 19 December 2006 setting maximum levels for certain contaminants in foodstuff. Off. J. Eur. Union 2006, 364, 5-24.

51. Smolders, E. Cadmium uptake by plants. Int. J. Occup. Med. Environ. 2001, 14, 177-183. 
52. Yusuf, M.; Fariduddin, Q.; Hayat, S.; Ahmad, A. Nickel: An Overview of Uptake, Essentiality and Toxicity in Plants. Bull. Environ. Contam. Toxicol. 2011, 86, 1-17. [CrossRef] [PubMed]

53. He, S.; He, Z.; Yang, X.; Baligar, V.C. Chapter Three-Mechanisms of nickel uptake and hyperaccumulation by plants and implications for soil remediation. Adv. Agron. 2012, 117, 117-179.

54. Song, Y.; Jin, L.; Wang, X. Cadmium absorption and transportation pathways in plants. Int. J. Phytoremed. 2017, 19, 133-141. [CrossRef] [PubMed]

55. Kazantzis, G. Thallium in the environment and health effects. Environ. Geochem. Health 2000, 22, $275-280$. [CrossRef]

56. Karbowska, B. Presence of thallium in the environment: Sources of contaminations, distribution and monitoring methods. Environ. Monit. Assess. 2016, 188, 640. [CrossRef]

57. Tschan, M.; Robinson, B.H.; Nodari, M.; Schulin, R. Antimony uptake by different plant species from nutrient solution, agar and soil. Environ. Chem. 2009, 6, 144-152. [CrossRef]

58. Woodman, K.K.; Baratoux, L.; Somda, A.; Siebenaller, L. The Youga gold deposit, Burkina Faso. Ore Geol. Rev. 2016, 78, 631-638. [CrossRef]

59. Joint, FAO/WHO Expert Committee on Food Additives, and World Health Organization. Evaluation of Certain Food Additives and Contaminants. In Thirty-Third Report of the Joint FAO/WHO Expert Committee on Food Additives; WHO Technical Report Series, No. 776; Joint FAO/WHO Expert Committee on Food Additives: Geneva, Switzerland, 1989.

60. Joint, FAO/WHO Expert Committee on Food Additives, and World Health Organization. In Summary and Conclusions of the Seventy Third Meeting of the Joint FAO/WHO Expert Committee on Food Additive; JECFA/73/SC; Joint FAO/WHO Expert Committee on Food Additives: Geneva, Switzerland, 2010.

61. Baars, A.J.; Theelen, R.M.C.; Janssen, P.J.C.M.; Hesse, J.M.; van Apeldoorn, M.E.; Meijerink, M.C.M.; Verdam, L.; Zeilmaker, M.J. Re-Evaluation of Human-Toxicological Maximum Permissible Risk Levels; RIVM Report 711701 025; National Institute of Public Health and the Environment: Bilthoven, The Netherlands, 2001.

62. Joint, FAO/WHO Expert Committee on Food Additives, and World Health Organization. Food Additives and Contaminants; Codex Alimentarius Commission, Joint FAO/WHO Food Standards Program, ALI-NORM01/12A; Joint FAO/WHO Expert Committee on Food Additives: The Hague, The Netherlands, 2001.

63. Joint, FAO/WHO Expert Committee on Food Additives, and World Health Organization. Safety Evaluation of Certain Contaminants in Food; Prepared by the Seventy-Second Meeting of the Joint FAO/WHO Expert Committee on Food Additives (JECFA), Mercury (Addendum); Food and Agriculture Organization of the United Nations: Rome, Italy; Joint FAO/WHO Expert Committee on Food Additives: Geneva, Switzerland, 2011.

64. WHO. Guideline for Drinking Water Quality, 3rd ed.; Incorporating First and Second Addenda. Volume 1 Recommendations; World Health Organization: Geneva, Switzerland, 2008.

65. Sander, S.; Kappenstein, O.; Ebner, I.; Fritsch, K.A.; Schmidt, R.; Pfaff, K.; Luch, A. Release of aluminium and thallium ions from uncoated food contact materials made of aluminium alloys into food and food simulant. PLoS ONE 2018, 13, e0200778. [CrossRef]

66. Ministry of the Environment. Regulation of the Minister of the Environment of 1 September 2016 on the conduct of the assessment of contamination of the surface of the earth. J. Lows 2016, 1396, 1-86.

67. Shar, G.Q.; Kazi, T.G.; Jatoi, W.B.; Makhija, P.M.; Sahito, S.B.; Shar, A.H.; Soomro, F.M. Determination of heavy metals in eight barley cultivars collected from wheat research station Tandojam, Sindh, Pakistan. Pak. J. Anal. Environ. Chem. 2013, 14, 47-53.

68. Ibrahim, K.N.; Yet, Z.R.; Som, A.M.; Razali, N.; Rahaizah, N.A.M.; Othman, E.N.; Burok, N.A.; Yunos, Y.M.; Othman, R.; Yahya, T.F.T. Heavy Metal Concentration (Pb, Cu, Fe, Zn, Ni) in Plant Parts of Zea Mays L. Cultivated in Agricultural Area Near Alor Gajah, Melaka, Malaysia. Am. J. Environ. Eng. 2015, 5, 8-12.

69. Eticha, T.; Hymete, A. Determination of some heavy metals in barley locally grown for brewing and it's malt in Ethiopia. J. Bioanal. Biomed. 2015, 7, 171-173.

70. Postawa, A.; Motyka, J. Selected trace elements and metals in groundwater within Permian sediments near Olkusz (Zn-Pb ore mining region, S Poland). Environ. Sci. Pollut. Res. 2019, 26, 34-43. [CrossRef] [PubMed]

71. Krzaklewski, W.; Barszcz, J.; Małek, S.; Kozioł, K.; Pietrzykowski, M. Contamination of forest soils in the vicinity of the sedimentation pond after zinc and lead ore flotation (in the region of Olkusz, southern Poland). Water Air Soil Pollut. 2004, 159, 151-164. [CrossRef] 
72. Potysz, A.; Kierczak, J.; Pietranik, A.; Kądziołka, K. Mineralogical, geochemical, and leaching study of historical Cu-slags issued from processing of the Zechstein formation (Old Copper Basin, south-western Poland). Appl. Geochem. 2018, 98, 22-35. [CrossRef]

73. Waroszewski, J.; Sprafke, T.; Kabała, C.; Kobierski, M.; Kierczak, J.; Musztyfaga, E.; Loba, A.; Mazurek, R.; Łabaz, B. Tracking textural, mineralogical and geochemical signatures in soils developed from basalt-derived materials covered with loess sediments (SW Poland). Geoderma 2019, 337, 983-997. [CrossRef]

74. Wieczorek, J.; Wieczorek, Z.; Bieniaszewski, T. Cadmium and lead content in cereal grains and soil from cropland adjacent to roadways. Pol. J. Environ. Stud. 2005, 14, 535-540.

75. Kan, A. Characterization of the fatty acid and mineral composition of selected cereal cultivars from Turkey. Rec. Nat. Prod. J. 2015, 9, 124-134.

76. Shaukat, S.S.; Rao, T.A.; Khan, M.A. Impact of sample size on principal component analysis ordination of an environmental data set: Effects on eigenstructure. Ekologia (Bratisl.) 2016, 35, 173-190. [CrossRef]

77. Dochtermann, N.A.; Jenkins, S.H. Mutivariate methods and small sample sizes. Ethol. Int. J. Behav. Biol. 2011, 117, 95-101.

78. Rai, P.K.; Lee, S.S.; Zhang, M.; Tsang, Y.F.; Kim, K.H. Heavy metals in food and crops: Health risks, fate, mechanisms, and management. Environ. Int. 2019, 125, 365-385. [CrossRef] [PubMed]

79. Gambuś, F.; Wieczorek, J. Pollution of fertilizers with heavy metals. Ecol. Chem. Eng. A 2012, 19, 353-360.

80. Irshad, M.; Malik, A.H.; Shaukat, S.; Mushtaq, S.; Ashraf, M. Characterization of heavy metals in livestock manures. Pol. J. Environ. Stud. 2013, 22, 1257-1262.

81. Armbruster, D.A.; Pry, T. Limit of blank, limit of detection and limit of quantification. Clin. Biochem. Rev. 2008, 29 (Suppl. I), 49-52.

82. EFSA. Scientific Opinion on Arsenic in Food; EFSA Panel on Contaminants in the Food Chain (CONTAM); European Food Safety Authority (EFSA): Parma, Italy, 2009; Volume 7, p. 1351.

83. EFSA. Scientific Opinion on the Risk for Public Health Related to the Presence of Mercury and Methylmercury in Food; EFSA Panel On Contaminants in The Food Chain (CONTAM); European Food Safety Authority (EFSA): Parma, Italy, 2012; Volume 10, p. 2985.

84. EFSA. Scientific Opinion on the Risks to Public Health Related to the Presence of Nickel in Food and Drinking Water; EFSA Panel on Contaminants in the Food Chain (CONTAM); European Food Safety Authority (EFSA): Parma, Italy, 2015; Volume 13, p. 4002.

85. EFSA. Cadmium Dietary Exposure in the European Population; Scientific Report of EFSA; European Food Safety Authority (EFSA): Parma, Italy, 2012; Volume 10, p. 2551.

86. EFSA. Scientific Opinion on Dietary Reference Values for Copper; EFSA Panel on Dietetic Products, Nutrition and Allergies (NDA); European Food Safety Authority (EFSA): Parma, Italy, 2015; Volume 13, p. 4253.

87. EFSA. Scientific Opinion on Dietary Reference Values for Zinc; EFSA Panel on Dietetic Products, Nutrition and Allergies (NDA); European Food Safety Authority (EFSA): Parma, Italy, 2014; Volume 12, p. 3844. 